\title{
Journal of

\section{Optimization of $\mathrm{N}$-Benzoylindazole Derivatives as Inhibitors of Human Neutrophil Elastase}

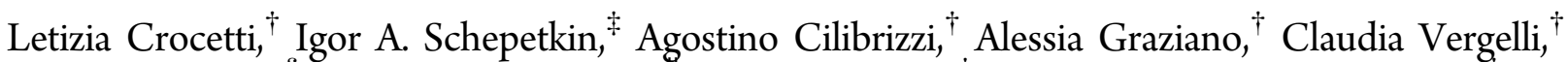 \\ Donatella Giomi, ${ }^{\S}$ Andrei I. Khlebnikov, ${ }^{\Uparrow}$ Mark T. Quinn, ${ }^{\ddagger}$ and Maria Paola Giovannoni*, ${ }^{\dagger}$ \\ ${ }^{\dagger}$ NEUROFARBA, Sezione di Farmaceutica e Nutraceutica, Università degli Studi di Firenze, Via Ugo Schiff 6, 50019 Sesto Fiorentino, \\ Italy \\ ${ }^{\ddagger}$ Department of Immunology and Infectious Diseases, Montana State University, Bozeman, Montana 59717, United States \\ ${ }^{\S}$ Dipartimento di Chimica, Università degli Studi di Firenze, Via della Lastruccia 3, 50019 Sesto Fiorentino, Italy \\ "Department of Chemistry, Altai State Technical University, Barnaul, Russia
}

Supporting Information

ABSTRACT: Human neutrophil elastase (HNE) is an important therapeutic target for treatment of pulmonary diseases. Previously, we identified novel $\mathrm{N}$ benzoylindazole derivatives as potent, competitive, and pseudoirreversible HNE inhibitors. Here, we report further development of these inhibitors with improved potency, protease selectivity, and stability compared to our previous leads. Introduction of a variety of substituents at position 5 of the indazole resulted in the potent inhibitor $20 \mathrm{f}\left(\mathrm{IC}_{50} \sim 10 \mathrm{nM}\right)$ and modifications at position 3 resulted the most potent compound in this series, the $3-\mathrm{CN}$ derivative $\mathbf{5 b}\left(\mathrm{IC}_{50}=7 \mathrm{nM}\right)$; both derivatives demonstrated good stability and specificity for HNE versus other serine proteases. Molecular docking of selected N-benzoylindazoles into the HNE binding domain suggested that inhibitory activity depended on geometry of the ligand-enzyme complexes. Indeed, the ability of a ligand to form a Michaelis complex and favorable conditions for proton transfer between Hys57, Asp102, and Ser195 both affected activity.

\section{INTRODUCTION}

Human neutrophil elastase (HNE) is a member of the chymotrypsin superfamily of serine proteases involved in the response to inflammatory stimuli. ${ }^{1,2} \mathrm{HNE}$ is stored in azurophilic granules of neutrophils and is very aggressive and cytotoxic, as its substrates include many components of the extracellular matrix. ${ }^{3}$ Because of the destructive potency of $\mathrm{HNE}$, its extracellular activity is regulated under physiological conditions by endogenous inhibitors such as $\alpha_{1}$-proteinase inhibitor ( $\alpha 1$-PI) and $\alpha_{2}$-macroglobulin. ${ }^{4,5}$ When the appropriate balance between HNE and its inhibitors fails in favor of the protease, the excess HNE activity may lead to tissue damage and the consequent development of a variety of diseases. Among the pathologies associated with increased HNE activity are acute respiratory distress syndrome (ARDS), ${ }^{6}$ chronic obstructive pulmonary disease (COPD), ${ }^{7,8}$ cystic fibrosis (CF), ${ }^{9}$ and other disorders with an inflammatory component such as atherosclerosis, psoriasis, and dermatitis. ${ }^{10-14}$ Recently $\mathrm{HNE}$ has also been implicated in the progression of nonsmall cell lung cancer progression. ${ }^{15}$ Thus, a number of clinical observations indicate that HNE represents a good therapeutic target for the treatment of inflammatory diseases and might be of value as therapeutic agents in lung cancer. ${ }^{15-20}$

The design of new HNE inhibitors has focused primarily on the development of different inhibitor types, including mechanism-based inhibitors, acylating-enzyme inhibitors, transition-state analogues, and noncovalent inhibitors. ${ }^{16-20}$ Despite the large number of HNE inhibitors described in the literature, Sivelestat is the only nonpeptidic inhibitor marketed, and it is limited to use in Japan and Korea for the treatment of acute lung injury, since its development in the USA was terminated in $2003{ }^{21,22}$ On the other hand, the neutrophil elastase inhibitor AZD9668 is currently being evaluated in clinical trials for patients with bronchiectasis and COPD. ${ }^{23,24}$

Recently, we discovered that $\mathrm{N}$-benzoylpyrazoles and $\mathrm{N}$ benzoylindazoles are potent HNE inhibitors. ${ }^{25-27}$ In the present studies, we further optimize HNE inhibitors with an $\mathrm{N}$-benzoylindazole scaffold and evaluate their biological activity. Introduction of a variety of substituents at the phenyl ring of the indazole nucleus and elaboration of the ester function at position 3 demonstrated that the cyclic amides, as well as the benzoyl fragment at position 1, are essential for activity. Studies on the most active derivatives, which were active in the low nanomolar range, showed that these compounds are competitive, pseudoirreversible inhibitors of $\mathrm{HNE}$, with an appreciable selectivity toward HNE versus other kinases tested. We also utilized molecular modeling to evaluate binding of the compounds to the HNE active site and determined that both the ability of an inhibitor to form a Michaelis complex and favorable conditions for proton transfer between His57, Asp102, and Ser195 affected inhibitory activity. Thus, the $N$ -

Received: May 20, 2013

Published: July 12, 2013 
benzoylindazole scaffold has great potential for the development of additional potent HNE inhibitors.

\section{CHEMISTRY}

All final compounds were synthesized as reported in Schemes $1-6$, and the structures were confirmed on the basis of analytical and spectral data. The synthetic pathway leading to the final benzoyl- $1 H$-indazoles $\mathbf{5 a - e}$ and $\mathbf{8}$, which are substituted at position 3 of the indazole, is depicted in Scheme 1. Compounds $\mathbf{5 a - d}$ were obtained starting from the

\section{Scheme $1^{a}$}

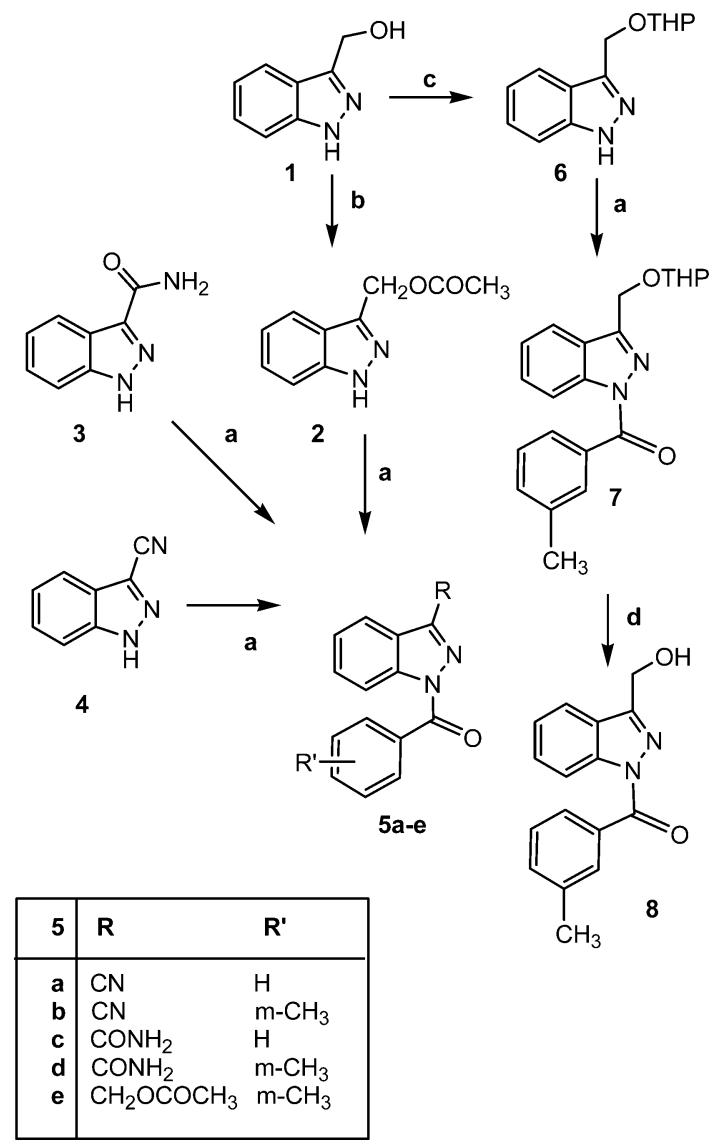

${ }^{a}$ Reagents and conditions: (a) $\mathbf{5 a}-\mathbf{c}, \mathbf{e}$ : $\mathrm{Ar}-\mathrm{COCl}, \mathrm{NEt}_{3}$, anhydrous $\mathrm{CH}_{2} \mathrm{Cl}_{2},{ }^{\circ} \mathrm{C}, 2 \mathrm{~h}$ and then rt, 2-12 h. 5d: step 1, $m$-toluic acid, $\mathrm{NEt}_{3}$, anhydrous THF, $-7 /-5{ }^{\circ} \mathrm{C}, 30 \mathrm{~min}$; step 2 , ClCOOEt, $0{ }^{\circ} \mathrm{C}, 1 \mathrm{~h}$ and then rt, $24 \mathrm{~h}$; (b) conc $\mathrm{CH}_{3} \mathrm{COOH}$, conc $\mathrm{H}_{2} \mathrm{SO}_{4}, 100{ }^{\circ} \mathrm{C}, 2 \mathrm{~h}$; (c) $\left(\mathrm{NH}_{4}\right)_{2} \mathrm{Ce}\left(\mathrm{NO}_{3}\right)_{6}$, anhydrous $\mathrm{CH}_{3} \mathrm{CN}, 3$,4-dihydro-2H-pyrano, rt, 24 h; (d) $\mathrm{CH}_{2} \mathrm{Cl}_{2} / \mathrm{CF}_{3} \mathrm{COOH}$ 6:1, rt, 3 h.

previously described precursors 3 and $4,{ }^{28,29}$ following two different procedures: treatment with the appropriate benzoylchloride and $\mathrm{Et}_{3} \mathrm{~N}$ in anhydrous $\mathrm{CH}_{2} \mathrm{Cl}_{2}(\mathbf{5 a}-\mathbf{c})$ or treatment with $m$-toluic acid, $\mathrm{Et}_{3} \mathrm{~N}$, and ethyl cloroformate in anhydrous THF (5d). For synthesis of 5e, the (1H-indazol-3-yl)-methanol $\mathbf{1}^{30}$ was transformed into the ester derivative 2 , which was treated with $m$-toluoyl chloride and $\mathrm{Et}_{3} \mathrm{~N}$ in $\mathrm{CH}_{2} \mathrm{Cl}_{2}$ to obtain the final compound. The same precursor $\mathbf{1}^{30}$ was also used for the synthesis of compound 8. First, it was necessary to protect the alcohol function at position 3 with 3,4-dihydro- $2 \mathrm{H}$-pyran (compound 6), followed by insertion of the benzoyl fragment at $\mathrm{N}-1$, and finally removal of the protecting group with trifluoroacetic acid.
Scheme 2 shows the synthetic routes followed to obtain nitro-derivatives $14 a-h\left(14 e^{32}\right), 15$, and 16. Treatment of

Scheme $2^{a}$

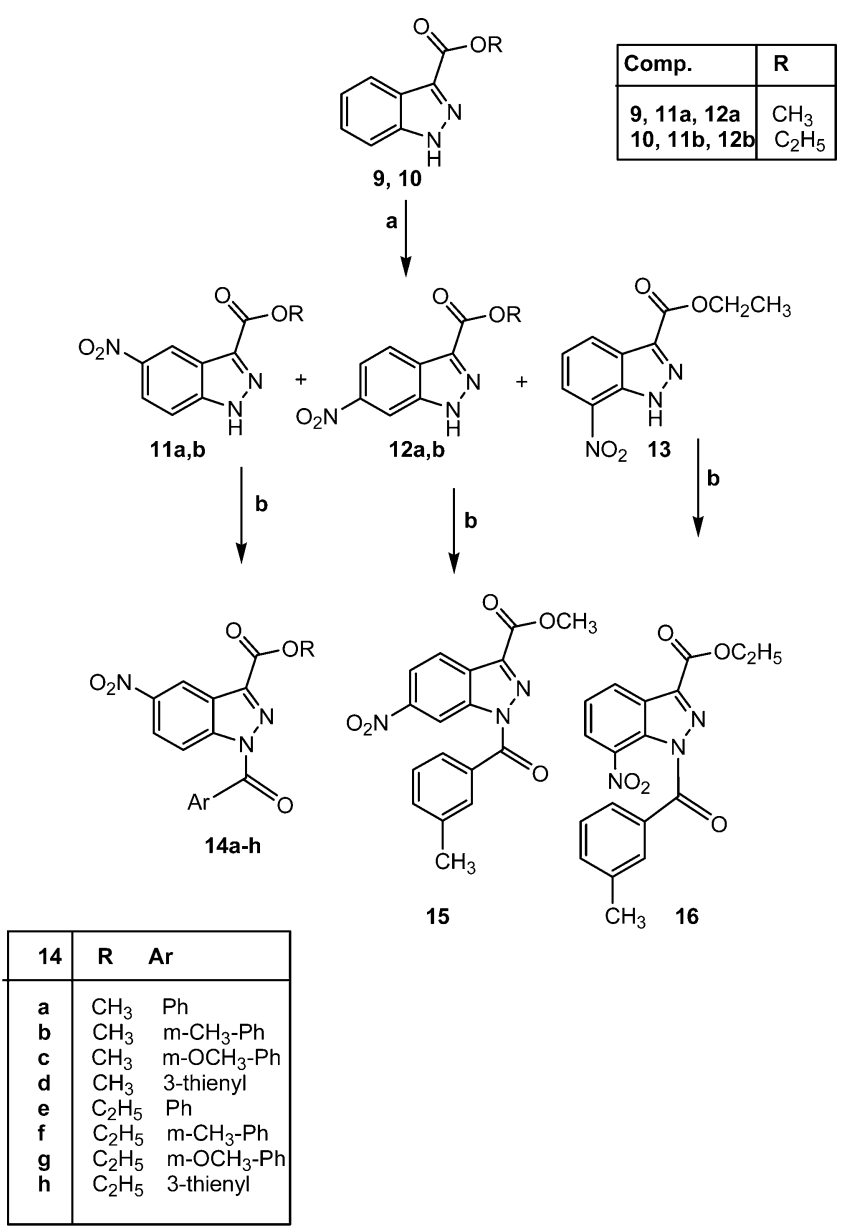

${ }^{a}$ Reagents and conditions: (a) conc $\mathrm{HNO}_{3}$, conc $\mathrm{H}_{2} \mathrm{SO}_{4}, 0{ }^{\circ} \mathrm{C}, 10 \mathrm{~min}$. (b) 14a,b,e,f, 15, 16: $\mathrm{Ar}-\mathrm{COCl}, \mathrm{NEt}_{3}$, anhydrous $\mathrm{CH}_{2} \mathrm{Cl}_{2}, 0{ }^{\circ} \mathrm{C}, 2 \mathrm{~h}$ and then rt, $2 \mathrm{~h}$. 14c,d,g,h: step 1, $\mathrm{Ar}-\mathrm{COOH}, \mathrm{SOCl}_{2}$, reflux, $1 \mathrm{~h}$; step 2, $\mathrm{NEt}_{3}$, anhydrous toluene, reflux, $6 \mathrm{~h}$.

compounds $9^{32}$ and $10^{31}$ with $\mathrm{H}_{2} \mathrm{SO}_{4} / \mathrm{HNO}_{3} 1: 1 \mathrm{v} / \mathrm{v}$ at $0{ }^{\circ} \mathrm{C}$ resulted in a mixture of the intermediates $\mathbf{1 1 a}, \mathbf{b},{ }^{32} \mathbf{1 2} \mathbf{a}, \mathbf{b}$ $\left(12 a^{33}\right)$, and $13^{34}$ in different yields (60\% for 11a,b, $10 \%$ for $12 \mathbf{a}, \mathbf{b}$, and $5 \%$ for 13 ), which were separated by column chromatography and subsequently transformed into the final compounds $14 a-h, 15$, and 16 following the same procedures, as described previously.

The 5-amino and 5-alkyl(aryl)amido derivatives 18, 19, and $20 \mathrm{a}-\mathrm{h}$ were obtained starting from a common precursor, the 5$\mathrm{NO}_{2}$ derivative 14f described above, which was transformed into the corresponding 5-amino 17 through catalytic reduction with a Parr instrument. Treatment of $\mathbf{1 7}$ with iodomethane, (cyclo)alkylcarbonyl chloride, or phenylboronic acid resulted in the final compounds $18,19,20 \mathrm{a}-\mathrm{g}$, and $20 \mathrm{~h}$, respectively.

In Scheme 4, the synthetic pathways leading to the 7sulfamoyl $(24 a, b)$ and 5-bromo $\left(26 \mathbf{a}-\mathbf{h}, 26 \mathrm{e}^{32}\right)$ indazole derivatives are shown. Introduction of the sulfamoyl moiety was carried out by treatment of the commercially available 21 with chlorosulfonic acid and 33\% aqueous ammonia (22). Esterification of $\mathbf{2 2}$ and further insertion of the benzoyl fragment resulted in the final compounds 24a,b. The 


\section{Scheme $3^{a}$}

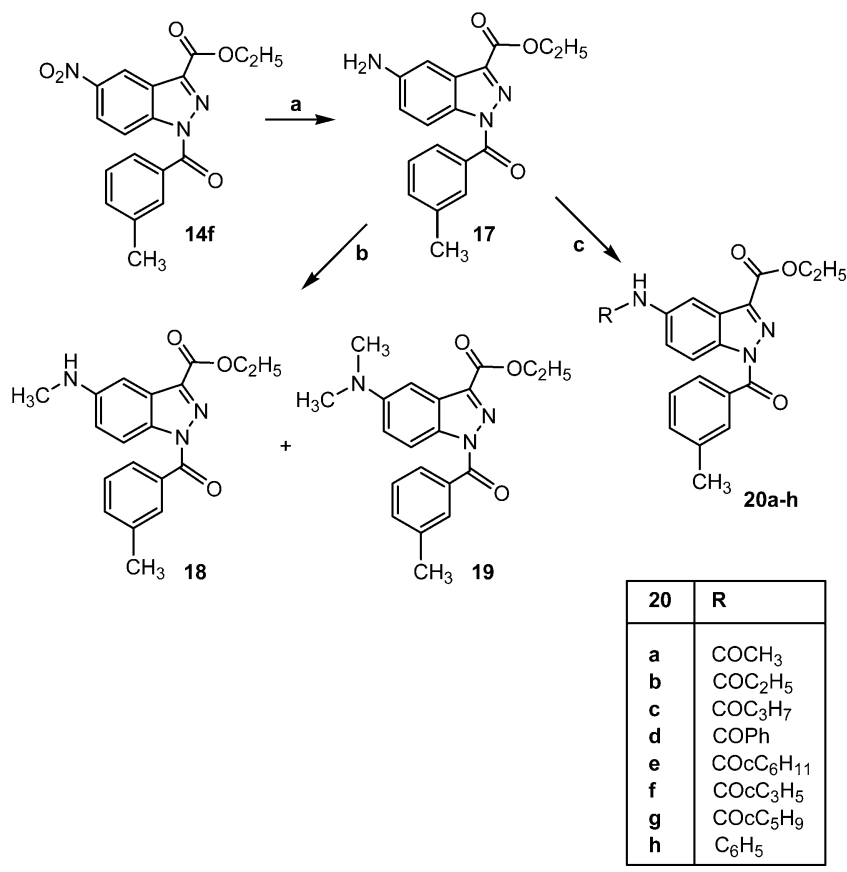

${ }^{a}$ Reagents and conditions: (a) $\mathrm{H}_{2}, \mathrm{Pd} / \mathrm{C}, \mathrm{EtOH}$, rt 2 h. (b) $\mathrm{CH}_{3} \mathrm{I}$, $\mathrm{K}_{2} \mathrm{CO}_{3}$, anhydrous DMF, $60{ }^{\circ} \mathrm{C}, 3$ h. (c) 20a-f: RCOCl, $\mathrm{NEt}_{3}$, anhydrous $\mathrm{CH}_{2} \mathrm{Cl}_{2}, 0{ }^{\circ} \mathrm{C}, 2 \mathrm{~h}, \mathrm{rt}, 2 \mathrm{~h}$. 20g: step 1, cyclopentanecarboxylic acid, $\mathrm{SOCl}_{2}$, reflux, $1 \mathrm{~h}$; step 2, $\mathrm{NEt}_{3}$, anhydrous toluene, reflux, 5-6 h. 20h: phenylboronic acid, anhydrous $\mathrm{CH}_{2} \mathrm{Cl}_{2}$, $\mathrm{Cu}(\mathrm{Ac})_{2}, \mathrm{NEt}_{3}, \mathrm{rt}, 2-4 \mathrm{~h}$.

substitution at position 7 (rather than at position 4) for these sulfamoyl derivatives was confirmed by performing spectral analyses on intermediate 23. For this compound, the substitution pattern was established on the basis of the ${ }^{1} \mathrm{H}$ NMR spectrum showing a pseudo triplet for $\mathrm{H}-5$ at $\delta 7.50$, as the result of the ${ }^{3} J_{\mathrm{H}, \mathrm{H}}$ couplings with $\mathrm{H}-4$ and $\mathrm{H}-6$ protons and definitively proved on the basis of heteronuclear correlation experiments. The g-HMBC spectrum clearly showed two crosspeaks for the ${ }^{3} J_{\mathrm{C}, \mathrm{H}}$ couplings of C-7a at $\delta 135.2$ with $\mathrm{H}-4$ and H-6 protons and a cross-peak for the ${ }^{3} J_{\mathrm{C}, \mathrm{H}}$ coupling of C-3a at $\delta$ 124.0 with $\mathrm{H}-5$. The 5-bromo derivatives $26 \mathbf{a}-\mathbf{h}$ shown in the same scheme were obtained from $25 \mathbf{a}, \mathbf{b}^{28}$ following the two procedures described for $5 \mathbf{a}-\mathbf{c}, \mathbf{e}$ and for $14 \mathbf{c}, \mathbf{d}, \mathbf{g}, \mathbf{h}$.

Many substituents at position 5 have been introduced following methods previously reported in the literature, ${ }^{35}$ which allowed us to obtain the indazole nucleus starting from the corresponding isatine. The synthetic route is shown in Scheme 5 using precursor isatines $27 \mathbf{a}-\mathbf{f}(27 \mathbf{a}-\mathbf{e}$ are commercially available; $\left.27 \mathbf{f}^{36}\right)$, which resulted in synthesis of compounds $\left.\mathbf{2 8 a}-\mathbf{f}\left(\mathbf{2 8 a}-\mathbf{c},{ }^{37} \mathbf{2 8 d}\right)^{38} \mathbf{2 8 \mathbf { e } ^ { 3 9 }}\right)$. Intermediates $28 \mathbf{a}-\mathbf{f}$ were then subjected to esterification, forming $\left.29 a-f(29 a-c)^{37} 29 d^{38}\right)$, which were finally converted into the desired compounds 31ai. To obtain $31 \mathbf{h}$, it was necessary to convert the $\mathrm{OCH}_{3}$ group of $29 \mathrm{~d}$ into $\mathrm{OH}$ by treatment with $\mathrm{BBr}_{3}$ in $\mathrm{CH}_{2} \mathrm{Cl}_{2}$ under nitrogen at $-78{ }^{\circ} \mathrm{C}$, followed by treatment with $m$-toluic acid, $\mathrm{Et}_{3} \mathrm{~N}$, and diethylcyanophosphonate (DCF) in dimethylformamide (31h).

Lastly, the synthesis of 33 (Scheme 6) was performed, starting from precursor $32^{40}$ and using the same conditions as described for compounds 5a-c,e (see Scheme 1).

\section{BIOLOGICAL RESULTS AND DISCUSSION}

Structure-Activity Relationship Analysis. All compounds were evaluated for their ability to inhibit HNE, and the results are reported in Tables 1-3, together with representative reference compounds from the previous series of $\mathrm{N}$-benzoylindazole-derived $\mathrm{HNE}$ inhibitors (designated as compounds $\mathbf{A}$ through $\mathbf{H}$ here). ${ }^{25}$ Keeping at positions 1 and 3 those substituents that produced the best results in the previous series, ${ }^{25}$ we first introduced a variety of groups at position 5 of the indazole nucleus, such as nitro, bromine, chlorine, (substituted) amino, etc. (Table 1). The introduction of substituents was generally favorable for HNE inhibitory activity, and most of the newly synthesized compounds showed 1 order of magnitude higher or a similar activity compared to the unsubstituted reference compounds $\mathbf{A}-\mathbf{H}$. In particular, introduction of a nitro group led to the most active compounds, which had $\mathrm{IC}_{50}$ values of $15-50 \mathrm{nM}$, irrespective of substituents $A r$ and $R_{1}$ at positions 1 and 3, respectively (compounds $14 \mathbf{a}-\mathbf{h}$ ). Likewise, the presence of an amide (compounds $20 \mathrm{a}-\mathrm{c}, 20 \mathrm{f}$, and $20 \mathrm{~g}$ ) was beneficial for activity, and these derivatives had similar activity as the 5-nitro derivatives $\left(\mathrm{IC}_{50}=12-50 \mathrm{nM}\right)$ (Table 1). Results for these 5 -amidic derivatives $(20 a-g)$ suggested the importance of steric hindrance by the group linked to the amide $\mathrm{CO}$ because the most bulky phenyl (20d) and cyclohexyl (20e) derivatives were less active by about 1 order of magnitude $\left(\mathrm{IC}_{50}=0.21\right.$ and $0.10 \mu \mathrm{M}$, respectively). Introduction of bromine resulted in increased potency for all compounds of this series $(26 a-h)$ compared to reference compounds $\mathbf{A}-\mathbf{H}$ (Table 1). Compounds containing methyl (31a), chlorine (31b), fluorine (31c), methoxy (31d,e), or trifluoromethoxy (31g) at the same position increased HNE inhibitory activity by 2-3-fold compared to the reference compounds $\mathbf{A}$ and $\mathbf{F}$, with the exception of 31f, which had an $\mathrm{IC}_{50}=60 \mathrm{nM}$. However, the 5(substituted)amino derivatives 17-19 and 20h retained HNE inhibitory activity in the same activity range as reference compound A (Table 1). On the other hand, 5-OH (31h) and $5-\mathrm{SO}_{2} \mathrm{NH}_{2}$ (31i) had low or no activity, respectively. Thus, the introduction of substituents at position 5 of the indazole nucleus is clearly beneficial for activity; however, there does not appear to be a generalizable correlation between activity and nature of the substituents. On the other hand, it is clear that acidic groups, such as $\mathrm{OH}$ and $\mathrm{SONH}_{2}$, are not tolerated at this position because compounds $31 \mathrm{~h}$ and $31 \mathrm{i}$ had low or no activity. Regarding the variety of other substituents and taking into account their different electronic and/or steric properties, we hypothesize that an electron withdrawing group within a given size is necessary to improve the potency. Aside from this characteristic, and with the exception of the limitations of an acid group mentioned above, compounds with other substituents retained similar levels of activity as their unsubstituted analogues.

Evaluation of C-6 and C-7 substitutions (Table 2) showed that the 6-substituted nitroderivative $15\left(\mathrm{IC}_{50}=20 \mathrm{nM}\right)$ was as active as its 5-isomer $14 \mathrm{~b}$, while introduction of group at position 7 gave rise to inactive compounds $16,24 a$, and $24 b$. Thus the C-6 position seems to be modifiable, while the total inactivity of 7-substituted derivatives confirms that the position neighboring the amidic nitrogen must be unsubstituted to allow free rotation of $\mathrm{N}-\mathrm{CO}$ bond, which is consistent with our previous observations with other $\mathrm{N}$-benzoylindazole derivatives. $^{25}$ 


\section{Scheme $4^{a}$}<smiles></smiles><smiles>CCOC(=O)c1n[nH]c2c(S(N)(=O)=O)cccc12</smiles><smiles>C1CC1</smiles><smiles>[Y4]c1cccc(C(=O)n2nc(C(=O)OCC)c3cccc(S(N)(=O)=O)c32)c1</smiles>

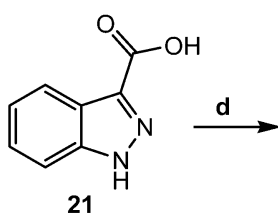

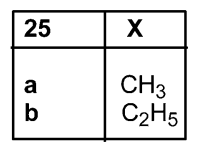<smiles>[R]OC(=O)c1n[nH]c2ccccc12</smiles>

e<smiles>[R]OC(=O)c1n[nH]c2ccc(Br)cc12</smiles>
25a,b<smiles>[R]OC(=O)c1nn(C([Z17])=O)c2ccc(Br)cc12</smiles>

26a-h

\begin{tabular}{|l|l|}
\hline $\mathbf{2 4}$ & $\mathbf{X}$ \\
\hline $\mathbf{a}$ & $\mathrm{H}$ \\
$\mathbf{b}$ & $\mathrm{m}-\mathrm{CH}_{3}$ \\
\hline
\end{tabular}

\begin{tabular}{|lll|}
\hline $\mathbf{2 6}$ & $\mathbf{R}$ & \multicolumn{1}{c|}{$\mathbf{A r}$} \\
\hline $\mathbf{a}$ & $\mathrm{CH}_{3}$ & $\mathrm{Ph}$ \\
$\mathbf{b}$ & $\mathrm{CH}_{3}$ & m- $\mathrm{CH}_{3}-\mathrm{Ph}$ \\
$\mathbf{c}$ & $\mathrm{CH}_{3}$ & m- $-\mathrm{OCH}_{3}-\mathrm{Ph}$ \\
$\mathbf{d}$ & $\mathrm{CH}_{3}$ & 3-thienyl \\
$\mathbf{e}$ & $\mathrm{C}_{2} \mathrm{H}_{5}$ & $\mathrm{Ph}$ \\
$\mathbf{f}$ & $\mathrm{C}_{2} \mathrm{H}_{5}$ & m- $\mathrm{CH}_{3}-\mathrm{Ph}$ \\
$\mathbf{g}$ & $\mathrm{C}_{2} \mathrm{H}_{5}$ & m-OCH \\
$\mathbf{h}$ & $\mathrm{C}_{2} \mathrm{H}_{5}$ & 3-thienyl \\
\hline
\end{tabular}

${ }^{a}$ Reagents and conditions: (a) Step $1, \mathrm{H}_{3} \mathrm{SO}_{2} \mathrm{Cl}, 0{ }^{\circ} \mathrm{C}-$ reflux, $4-5 \mathrm{~h}$; step 2, 33\% $\mathrm{NH}_{3}, 0{ }^{\circ} \mathrm{C}$. (b) Anhydrous EtOH, conc $\mathrm{H}_{2} \mathrm{SO}_{4}$, reflux, 5 h. (c) Ar$\mathrm{COCl}, \mathrm{NEt}_{3}$, anhydrous $\mathrm{CH}_{2} \mathrm{Cl}_{2}, 0^{\circ} \mathrm{C}, 2 \mathrm{~h}$, rt, $2 \mathrm{~h}$. (d) Anhydrous EtOH or $\mathrm{MeOH}$, conc $\mathrm{H}_{2} \mathrm{SO}_{4}$, reflux, $5 \mathrm{~h}$; (e) $\mathrm{Br}_{2}$, anhydrous DMF, $0{ }^{\circ} \mathrm{C}, 1 \mathrm{~h}, \mathrm{rt}$,

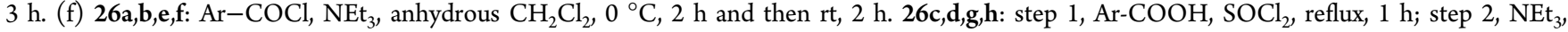
anhydrous toluene, reflux, $6 \mathrm{~h}$.

The next modifications were performed at position 3 (Table 3 ). The introduction of an hydroxymethyl (8) or an inverse ester (5e) was detrimental for activity, while the replacement of the ester function with a primary amide gave different results depending on the group at position 1 ( $\mathbf{5} \mathbf{c}$ and $\mathbf{5 d}$ ). Conversely, a remarkable increase in potency was obtained by introducing a $\mathrm{CN}$ group, which resulted in the most active derivative of this series $(\mathbf{5 b})$ with an $\mathrm{IC}_{50}$ of $7 \mathrm{nM}$. To verify if an additive effect was possible to achieve by inserting in the same molecule both of the groups that separately led to increased activity (i.e., 5nitro derivative $14 \mathrm{c} ; 3-\mathrm{CN}$ derivative $5 \mathbf{b}$ ), we synthesized compound 33. However, no additive effects were observed, as 33 had similar inhibitory activity $\left(\mathrm{IC}_{50}=31 \mathrm{nM}\right)$ as the singly substituted derivatives $\mathbf{1 4} \mathrm{c}$ and $\mathbf{5 b}$.

Inhibitor Specificity. To evaluate inhibitor specificity, we analyzed effects of the 10 most potent $N$-benzoylindazoles on four other serine proteases, including human pancreatic chymotrypsin (EC 3.4.21.1), human thrombin (EC 3.4.21.5), human plasma kallikrein (EC 3.4.21.34), and human urokinase (EC 3.4.21.73), and an aspartic protease, cathepsin D (EC 3.4.23.5). As shown in Table 4, none of the tested derivatives inhibited cathepsin $\mathrm{D}$ and only compound 14a inhibited kallikrein. Compound $\mathbf{5 b}$ inhibited thrombin and urokinase at micromolar concentrations. Although all tested compounds inhibited chymotrypsin at nanomolar concentrations, compound 20f had the lowest activity for this enzyme. Moreover, only compound $20 \mathrm{f}$ had no inhibitory activity for urokinase (Table 4). Thus, compounds $\mathbf{5 b}$ and $\mathbf{2 0 f}$ appear to be the most specific HNE inhibitors.

Stability and Kinetic Features. The most potent and specific $N$-benzoylindazoles were further evaluated for chemical stability in aqueous buffer using spectrophotometry to detect compound hydrolysis. As shown in Figure 1, the absorbance maxima at 242 and $322 \mathrm{~nm}$ for compound $\mathbf{5 b}$ decreased over time, indicating that this compound was hydrolyzed almost completely after $35 \mathrm{~min}$ in aqueous buffer with a $t_{1 / 2}$ of 21.7 min. The other nine compounds had $t_{1 / 2}$ values from 27.2 to $117.5 \mathrm{~min}$ (Table 5), indicating that the tested $\mathrm{N}$ benzoylindazoles were more stable than our previously described HNE inhibitors with the $N$-benzoylpyrazole scaffold. $^{25}$

The relatively rapid rate of spontaneous hydrolysis allowed us to evaluate inhibitor reversibility over time. As shown in Figure 2, inhibition was maximal during the first $5 \mathrm{~h}$ for compounds 20b and 20f and during the first $4 \mathrm{~h}$ for compounds $5 \mathrm{~b}, 14 \mathrm{~b}, 14 \mathrm{f}, 15$, and $20 \mathrm{a}$ at $5 \mu \mathrm{M}$ concentrations. 
Scheme $5^{a}$

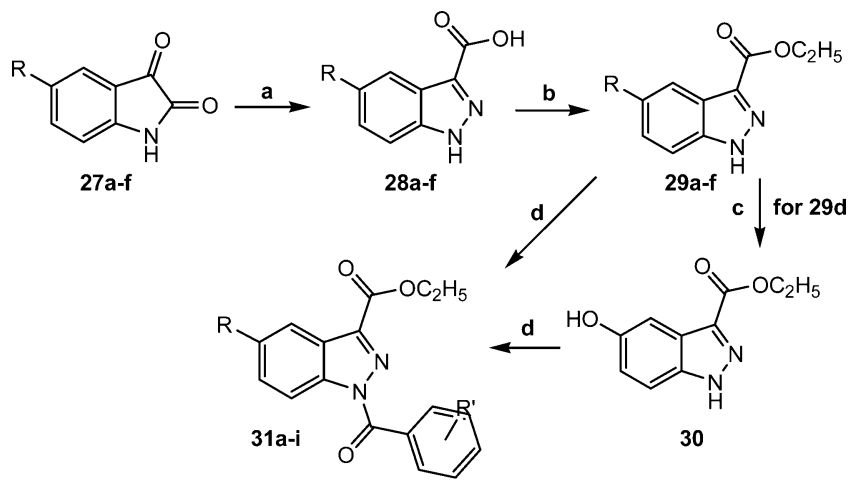

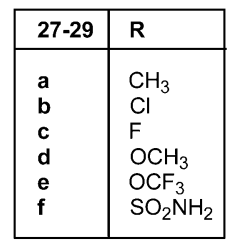

${ }^{a}$ Reagents and conditions: (a) step 1, 0.5 N NaOH, $\mathrm{H}_{2} \mathrm{O}, 30 \mathrm{~min}, 50$ ${ }^{\circ} \mathrm{C}$; step 2, $\mathrm{NaNO}_{2}$ sol, $\mathrm{H}_{2} \mathrm{SO}_{4}, 1 \mathrm{~h}, 0{ }^{\circ} \mathrm{C}$; step $3, \mathrm{SnCl}_{2} \cdot 2 \mathrm{H}_{2} \mathrm{O}$, conc $\mathrm{HCl}, 0{ }^{\circ} \mathrm{C}, 2 \mathrm{~h}$ and then rt, $12 \mathrm{~h}$. (b) anhydrous $\mathrm{EtOH}$, conc $\mathrm{H}_{2} \mathrm{SO}_{4}$, $100{ }^{\circ} \mathrm{C}, 5$ h. (c) for $29 \mathrm{~d}: \mathrm{BBr}_{3} / \mathrm{CH}_{2} \mathrm{Cl}_{2}(1 \mathrm{M}), \mathrm{N}_{2},-78{ }^{\circ} \mathrm{C}, 15 \mathrm{~min}$ and rt, 12 h. (d) $31 \mathrm{a}-\mathrm{g}, \mathrm{i}, \mathrm{Ar}-\mathrm{COCl}, \mathrm{NEt}_{3}$, anhydrous $\mathrm{CH}_{2} \mathrm{Cl}_{2}, 0{ }^{\circ} \mathrm{C}, 2 \mathrm{~h}$ and then rt, $2 \mathrm{~h}$; for $31 \mathrm{~h}, m$-toluic acid, DCF, $\mathrm{NEt}_{3}$, anhydrous DMF, 0 ${ }^{\circ} \mathrm{C}, 30 \mathrm{~min}$ and then $\mathrm{rt}, 12 \mathrm{~h}$.

\section{Scheme $6^{a}$}

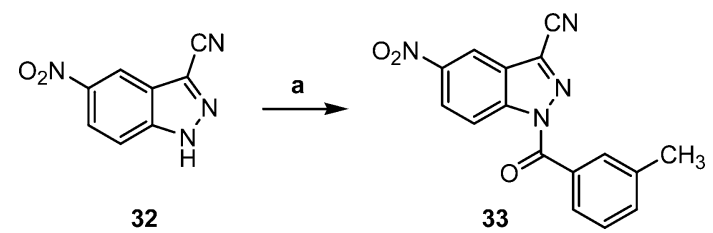

${ }^{a}$ Reagents and conditions: (a) $m$-toluoyl chloride, $\mathrm{NEt}_{3}$, anhydrous $\mathrm{CH}_{2} \mathrm{Cl}_{2}, 0{ }^{\circ} \mathrm{C}, 2 \mathrm{~h}$, and then $\mathrm{rt}, 2 \mathrm{~h}$.

However, inhibition by compounds 14a, 14g, and 14h was soon reversed, and recovery of HNE activity was observed by $\sim 1-2 \mathrm{~h}$ after treatment with up to $5 \mu \mathrm{M}$ of these compounds (Figure 2). Although the rate of reversibility for the last three compounds (14a, 14g, and $14 \mathrm{~h}$ ) correlated with the rate of spontaneous hydrolysis, this was not the case for the other $\mathrm{N}$ benzoylindazole derivatives tested. For example, hydrolysis of the acyl-enzyme complex for compound $\mathbf{5 b}$ was much slower than spontaneous hydrolysis of this nitrile derivative, and HNE was still inhibited to $80 \%$ of control level at $7 \mathrm{~h}$ after treatment (compare Figures 1 and 2). Thus, these results suggest that the active $N$-benzoylindazoles may be pseudoirreversible HNE inhibitors, which covalently attack the enzyme active site but can be reversed by hydrolysis of the acyl-enzyme complex, which is similar to the structurally related $\mathrm{N}$-benzoylpyrazolederived HNE inhibitors. ${ }^{25}$

To better understand the mechanism of action of these $\mathrm{N}$ benzoylindazole HNE inhibitors, we performed kinetic experiments with two of the most active compounds that had
Table 1. HNE Inhibitory Activity of Indazole Derivatives $14 a-h, 17-19,20 a-h, 26 a-h$, and $31 a-i$<smiles>[R]OC(=O)c1nn(C(=O)[Al])c2ccc([R2])cc12</smiles>

\begin{tabular}{|c|c|c|c|c|}
\hline compd & $\mathrm{Ar}$ & $\mathrm{R}_{1}$ & $\mathrm{R}_{2}$ & $\mathrm{IC}_{50}(\mu \mathrm{M})^{a}$ \\
\hline $14 \mathrm{a}$ & $\mathrm{Ph}$ & $\mathrm{CH}_{3}$ & $\mathrm{NO}_{2}$ & $0.03 \pm 0.011$ \\
\hline $14 \mathrm{~b}$ & $m-\mathrm{CH}_{3}-\mathrm{Ph}$ & $\mathrm{CH}_{3}$ & $\mathrm{NO}_{2}$ & $0.015 \pm 0.0018$ \\
\hline $14 \mathrm{c}$ & $m-\mathrm{OCH}_{3}-\mathrm{Ph}$ & $\mathrm{CH}_{3}$ & $\mathrm{NO}_{2}$ & $0.05 \pm 0.021$ \\
\hline $14 d$ & 3-thienyl & $\mathrm{CH}_{3}$ & $\mathrm{NO}_{2}$ & $0.05 \pm 0.019$ \\
\hline $14 \mathrm{e}^{32}$ & $\mathrm{Ph}$ & $\mathrm{C}_{2} \mathrm{H}_{5}$ & $\mathrm{NO}_{2}$ & $0.02 \pm 0.018$ \\
\hline $14 \mathrm{f}$ & $m-\mathrm{CH}_{3}-\mathrm{Ph}$ & $\mathrm{C}_{2} \mathrm{H}_{5}$ & $\mathrm{NO}_{2}$ & $0.02 \pm 0.028$ \\
\hline $14 \mathrm{~g}$ & $m-\mathrm{OCH}_{3}-\mathrm{Ph}$ & $\mathrm{C}_{2} \mathrm{H}_{5}$ & $\mathrm{NO}_{2}$ & $0.025 \pm 0.015$ \\
\hline $14 \mathrm{~h}$ & 3-thienyl & $\mathrm{C}_{2} \mathrm{H}_{5}$ & $\mathrm{NO}_{2}$ & $0.03 \pm 0.031$ \\
\hline 17 & $m-\mathrm{CH}_{3}-\mathrm{Ph}$ & $\mathrm{C}_{2} \mathrm{H}_{5}$ & $\mathrm{NH}_{2}$ & $0.33 \pm 0.042$ \\
\hline 18 & $m-\mathrm{CH}_{3}-\mathrm{Ph}$ & $\mathrm{C}_{2} \mathrm{H}_{5}$ & $\mathrm{NHCH}_{3}$ & $0.31 \pm 0.11$ \\
\hline 19 & $m-\mathrm{CH}_{3}-\mathrm{Ph}$ & $\mathrm{C}_{2} \mathrm{H}_{5}$ & $\mathrm{~N}\left(\mathrm{CH}_{3}\right)_{2}$ & $0.14 \pm 0.23$ \\
\hline $20 a$ & $m-\mathrm{CH}_{3}-\mathrm{Ph}$ & $\mathrm{C}_{2} \mathrm{H}_{5}$ & $\mathrm{NHCOCH}_{3}$ & $0.03 \pm 0.037$ \\
\hline $20 \mathrm{~b}$ & $m-\mathrm{CH}_{3}-\mathrm{Ph}$ & $\mathrm{C}_{2} \mathrm{H}_{5}$ & $\mathrm{NHCOC}_{2} \mathrm{H}_{5}$ & $0.018 \pm 0.021$ \\
\hline $20 \mathrm{c}$ & $m-\mathrm{CH}_{3}-\mathrm{Ph}$ & $\mathrm{C}_{2} \mathrm{H}_{5}$ & $\mathrm{NHCO} n \mathrm{C}_{3} \mathrm{H}_{7}$ & $0.05 \pm 0.012$ \\
\hline $20 \mathrm{~d}$ & $m-\mathrm{CH}_{3}-\mathrm{Ph}$ & $\mathrm{C}_{2} \mathrm{H}_{5}$ & $\mathrm{NHCOPh}$ & $0.21 \pm 0.13$ \\
\hline $20 \mathrm{e}$ & $m-\mathrm{CH}_{3}-\mathrm{Ph}$ & $\mathrm{C}_{2} \mathrm{H}_{5}$ & $\mathrm{NHCO} c \mathrm{C}_{6} \mathrm{H}_{11}$ & $0.10 \pm 0.11$ \\
\hline $20 f$ & $m-\mathrm{CH}_{3}-\mathrm{Ph}$ & $\mathrm{C}_{2} \mathrm{H}_{5}$ & $\mathrm{NHCO} c \mathrm{C}_{3} \mathrm{H}_{5}$ & $0.012 \pm 0.030$ \\
\hline $20 \mathrm{~g}$ & $m-\mathrm{CH}_{3}-\mathrm{Ph}$ & $\mathrm{C}_{2} \mathrm{H}_{5}$ & $\mathrm{NHCO} c \mathrm{C}_{5} \mathrm{H}_{9}$ & $0.05 \pm 0.029$ \\
\hline $20 \mathrm{~h}$ & $m-\mathrm{CH}_{3}-\mathrm{Ph}$ & $\mathrm{C}_{2} \mathrm{H}_{5}$ & NH-Ph & $0.33 \pm 0.052$ \\
\hline $26 a$ & $\mathrm{Ph}$ & $\mathrm{CH}_{3}$ & $\mathrm{Br}$ & $0.08 \pm 0.37$ \\
\hline $26 b$ & $m-\mathrm{CH}_{3}-\mathrm{Ph}$ & $\mathrm{CH}_{3}$ & $\mathrm{Br}$ & $0.08 \pm 0.11$ \\
\hline $26 \mathrm{c}$ & $m-\mathrm{OCH}_{3}-\mathrm{Ph}$ & $\mathrm{CH}_{3}$ & $\mathrm{Br}$ & $0.21 \pm 0.23$ \\
\hline $26 d$ & 3-thienyl & $\mathrm{CH}_{3}$ & $\mathrm{Br}$ & $0.16 \pm 0.21$ \\
\hline $26 \mathrm{e}^{32}$ & $\mathrm{Ph}$ & $\mathrm{C}_{2} \mathrm{H}_{5}$ & $\mathrm{Br}$ & $0.05 \pm 0.042$ \\
\hline $26 f$ & $m-\mathrm{CH}_{3}-\mathrm{Ph}$ & $\mathrm{C}_{2} \mathrm{H}_{5}$ & $\mathrm{Br}$ & $0.08 \pm 0.018$ \\
\hline $26 \mathrm{~g}$ & $m-\mathrm{OCH}_{3}-\mathrm{Ph}$ & $\mathrm{C}_{2} \mathrm{H}_{5}$ & $\mathrm{Br}$ & $0.27 \pm 0.088$ \\
\hline $26 \mathrm{~h}$ & 3-thienyl & $\mathrm{C}_{2} \mathrm{H}_{5}$ & $\mathrm{Br}$ & $0.26 \pm 0.12$ \\
\hline $31 \mathrm{a}$ & $m-\mathrm{CH}_{3}-\mathrm{Ph}$ & $\mathrm{C}_{2} \mathrm{H}_{5}$ & $\mathrm{CH}_{3}$ & $0.22 \pm 0.052$ \\
\hline $31 b$ & $m-\mathrm{CH}_{3}-\mathrm{Ph}$ & $\mathrm{C}_{2} \mathrm{H}_{5}$ & $\mathrm{Cl}$ & $0.15 \pm 0.033$ \\
\hline $31 \mathrm{c}$ & $m-\mathrm{CH}_{3}-\mathrm{Ph}$ & $\mathrm{C}_{2} \mathrm{H}_{5}$ & $\mathrm{~F}$ & $0.10 \pm 0.019$ \\
\hline $31 d$ & $\mathrm{Ph}$ & $\mathrm{C}_{2} \mathrm{H}_{5}$ & $\mathrm{OCH}_{3}$ & $0.08 \pm 0.021$ \\
\hline $31 \mathrm{e}$ & $m-\mathrm{CH}_{3}-\mathrm{Ph}$ & $\mathrm{C}_{2} \mathrm{H}_{5}$ & $\mathrm{OCH}_{3}$ & $0.14 \pm 0.027$ \\
\hline $31 \mathrm{f}$ & $\mathrm{Ph}$ & $\mathrm{C}_{2} \mathrm{H}_{5}$ & $\mathrm{OCF}_{3}$ & $0.06 \pm 0.018$ \\
\hline $31 g$ & $m-\mathrm{CH}_{3}-\mathrm{Ph}$ & $\mathrm{C}_{2} \mathrm{H}_{5}$ & $\mathrm{OCF}_{3}$ & $0.11 \pm 0.028$ \\
\hline $31 \mathrm{~h}$ & $m-\mathrm{CH}_{3}-\mathrm{Ph}$ & $\mathrm{C}_{2} \mathrm{H}_{5}$ & $\mathrm{OH}$ & $6.4 \pm 1.1$ \\
\hline $31 \mathrm{i}$ & $m-\mathrm{CH}_{3}-\mathrm{Ph}$ & $\mathrm{C}_{2} \mathrm{H}_{5}$ & $\mathrm{SO}_{2} \mathrm{NH}_{2}$ & $\mathrm{NA}^{b}$ \\
\hline$A^{25}$ & $m-\mathrm{CH}_{3}-\mathrm{Ph}$ & $\mathrm{C}_{2} \mathrm{H}_{5}$ & $\mathrm{H}$ & $0.41 \pm 0.11$ \\
\hline$B^{25}$ & $m-\mathrm{CH}_{3}-\mathrm{Ph}$ & $\mathrm{CH}_{3}$ & $\mathrm{H}$ & $0.13 \pm 0.051$ \\
\hline $\mathrm{C}^{25}$ & $m-\mathrm{OCH}_{3}-\mathrm{Ph}$ & $\mathrm{CH}_{3}$ & $\mathrm{H}$ & $0.55 \pm 0.21$ \\
\hline $\mathbf{D}^{25}$ & $m-\mathrm{OCH}_{3}-\mathrm{Ph}$ & $\mathrm{C}_{2} \mathrm{H}_{5}$ & $\mathrm{H}$ & $0.8 \pm 0.33$ \\
\hline $\mathrm{E}^{25}$ & $\mathrm{Ph}$ & $\mathrm{CH}_{3}$ & $\mathrm{H}$ & $0.089 \pm 0.031$ \\
\hline $\mathbf{F}^{25}$ & $\mathrm{Ph}$ & $\mathrm{C}_{2} \mathrm{H}_{5}$ & $\mathrm{H}$ & $0.40 \pm 0.19$ \\
\hline $\mathrm{G}^{25}$ & 3-thienyl & $\mathrm{CH}_{3}$ & $\mathrm{H}$ & $0.31 \pm 0.12$ \\
\hline $\mathbf{H}^{25}$ & 3-thienyl & $\mathrm{C}_{2} \mathrm{H}_{5}$ & $\mathrm{H}$ & $0.93 \pm 0.37$ \\
\hline
\end{tabular}

${ }^{a_{T}}$ The $\mathrm{IC}_{50}$ values are presented as the mean $\pm \mathrm{SD}$ of three independent experiments. ${ }^{b} \mathrm{NA}$ : no inhibitory activity was found at the highest concentration of compound tested $(50 \mu \mathrm{M})$.

favorable specificity profiles (5b and 20f). As shown in Figure 3 , the representative double-reciprocal Lineweaver-Burk plot of fluorogenic substrate hydrolysis by HNE in the absence and presence of compound $\mathbf{5 b}$ indicates that this compound is a 
Table 2. HNE Inhibitory Activity of Indazole Derivatives 15, 16 , and $24 a, b$<smiles>[R]OC(=O)c1nn(C(=O)[Al])c2c([R3])c([R2])ccc12</smiles>

\begin{tabular}{cllllc} 
compd & \multicolumn{1}{c}{$\mathrm{Ar}$} & \multicolumn{1}{c}{$\mathrm{R}_{1}$} & \multicolumn{1}{c}{$\mathrm{R}_{2}$} & \multicolumn{1}{c}{$\mathrm{R}_{3}$} & $\mathrm{IC}_{50}(\mu \mathrm{M})^{a}$ \\
\hline $\mathbf{1 5}$ & $m-\mathrm{CH}_{3}-\mathrm{Ph}$ & $\mathrm{CH}_{3}$ & $\mathrm{NO}_{2}$ & $\mathrm{H}$ & $0.02 \pm 0.018$ \\
$\mathbf{1 6}$ & $m-\mathrm{CH}_{3}-\mathrm{Ph}$ & $\mathrm{CH}_{3}$ & $\mathrm{H}$ & $\mathrm{NO}_{2}$ & $\mathrm{NA}^{b}$ \\
$\mathbf{2 4 a}$ & $\mathrm{Ph}$ & $\mathrm{C}_{2} \mathrm{H}_{5}$ & $\mathrm{H}$ & $\mathrm{SO}_{2} \mathrm{NH}_{2}$ & $\mathrm{NA}$ \\
$\mathbf{2 4 b}$ & $m-\mathrm{CH}_{3}-\mathrm{Ph}$ & $\mathrm{C}_{2} \mathrm{H}_{5}$ & $\mathrm{H}$ & $\mathrm{SO}_{2} \mathrm{NH}_{2}$ & $\mathrm{NA}$ \\
$\mathbf{A}^{25}$ & $m-\mathrm{CH}_{3}-\mathrm{Ph}$ & $\mathrm{C}_{2} \mathrm{H}_{5}$ & $\mathrm{H}$ & $\mathrm{H}$ & $0.41 \pm 0.11$ \\
$\mathbf{B}^{25}$ & $m-\mathrm{CH}_{3}-\mathrm{Ph}$ & $\mathrm{CH}_{3}$ & $\mathrm{H}$ & $\mathrm{H}$ & $0.13 \pm 0.051$ \\
$\mathbf{F}^{25}$ & $\mathrm{Ph}$ & $\mathrm{C}_{2} \mathrm{H}_{5}$ & $\mathrm{H}$ & $\mathrm{H}$ & $0.40 \pm 0.19$
\end{tabular}

${ }^{a_{T}}$ The $\mathrm{IC}_{50}$ values are presented as the mean $\pm \mathrm{SD}$ of three independent experiments. ${ }^{b}$ NA: no inhibitory activity was found at the highest concentration of compound tested $(50 \mu \mathrm{M})$.

Table 3. HNE Inhibitory Activity of Indazole Derivatives $5 a-e, 8$, and 33<smiles>[R]c1ccc2c(c1)c([R7])nn2C(=O)[Al]</smiles>

\begin{tabular}{clllc} 
compd & \multicolumn{1}{c}{$\mathrm{Ar}$} & \multicolumn{1}{c}{$\mathrm{R}_{1}$} & \multicolumn{1}{c}{$\mathrm{R}_{2}$} & $\mathrm{IC}_{50}(\mu \mathrm{M})^{a}$ \\
\hline $\mathbf{5 a}$ & $\mathrm{Ph}$ & $\mathrm{CN}$ & $\mathrm{H}$ & $0.04 \pm 0.011$ \\
$\mathbf{5 b}$ & $m-\mathrm{CH}_{3}-\mathrm{Ph}$ & $\mathrm{CN}$ & $\mathrm{H}$ & $0.007 \pm 0.0015$ \\
$\mathbf{5 c}$ & $\mathrm{Ph}$ & $\mathrm{CONH}_{2}$ & $\mathrm{H}$ & $0.26 \pm 0.042$ \\
$\mathbf{5 d}$ & $m-\mathrm{CH}_{3}-\mathrm{Ph}$ & $\mathrm{CONH}_{2}$ & $\mathrm{H}$ & $12.5 \pm 2.7$ \\
$\mathbf{5 e}$ & $m-\mathrm{CH}_{3}-\mathrm{Ph}$ & $\mathrm{CH}_{2} \mathrm{OCOCH}_{3}$ & $\mathrm{H}$ & $6.4 \pm 1.2$ \\
$\mathbf{8}$ & $m-\mathrm{CH}_{3}-\mathrm{Ph}$ & $\mathrm{CH}_{2} \mathrm{OH}$ & $\mathrm{H}$ & $\mathrm{NA}^{b}$ \\
33 & $m-\mathrm{CH}_{3}-\mathrm{Ph}$ & $\mathrm{CN}$ & $\mathrm{NO}_{2}$ & $0.031 \pm 0.018$ \\
$\mathbf{A}^{25}$ & $m-\mathrm{CH}_{3}-\mathrm{Ph}$ & $\mathrm{COOC}_{2} \mathrm{H}_{5}$ & $\mathrm{H}$ & $0.41 \pm 0.11$
\end{tabular}

${ }^{a_{T}}$ The $\mathrm{IC}_{50}$ values are presented as the mean $\pm \mathrm{SD}$ of three independent experiments. ${ }^{b} \mathrm{NA}$ : no inhibitory activity was found at the highest concentration of compound tested $(50 \mu \mathrm{M})$.

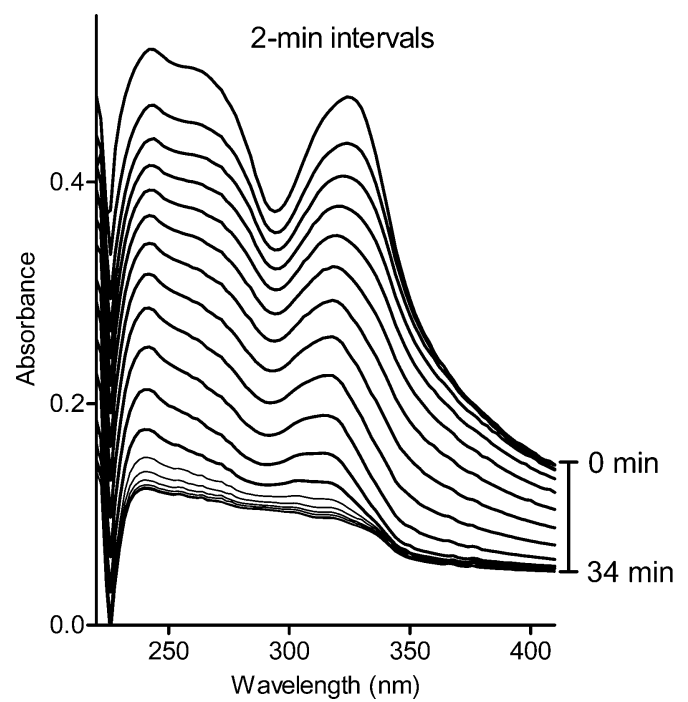

Figure 1. Analysis of changes in compound absorbance resulting from spontaneous hydrolysis. The changes in absorbance spectra of compound $5 \mathbf{b}(20 \mu \mathrm{M})$ were monitored over time with $2 \mathrm{~min}$ intervals in $0.05 \mathrm{M}$ phosphate buffer $\left(\mathrm{pH} 7.5,25^{\circ} \mathrm{C}\right)$. Representative scans are from three independent experiments.

Table 5. Half-Life $\left(t_{1 / 2}\right)$ for the Spontaneous Hydrolysis of Selected Indazole Derivatives

\begin{tabular}{ccc} 
compd & $\max (\mathrm{nm})^{a}$ & $t_{1 / 2}(\min )$ \\
\hline 5b & 242 & 21.7 \\
$\mathbf{1 4 f}$ & 274 & 117.5 \\
$\mathbf{1 4 g}$ & 272 & 27.2 \\
$\mathbf{2 0 a}$ & 262 & 78.8 \\
$\mathbf{1 4 h}$ & 272 & 32.8 \\
$\mathbf{1 4 a}$ & 268 & 37.9 \\
$\mathbf{1 4 b}$ & 270 & 47.8 \\
$\mathbf{1 5}$ & 268 & 41.5 \\
$\mathbf{2 0 b}$ & 266 & 51.0 \\
$\mathbf{2 0 f}$ & 266 & 51.7
\end{tabular}

${ }^{a}$ Absorption maximum used for monitoring spontaneous hydrolysis.

competitive HNE inhibitor. Similar results were observed for the kinetic analysis of compound 20f (data not shown).

Molecular Modeling. To evaluate complementarity of the inhibitors to the HNE binding site, we performed molecular docking studies of selected compounds (5b, 5d, 8, 14f, 26b,

Table 4. Analysis of Inhibitory Specificity for Selected Indazole Derivatives

\begin{tabular}{|c|c|c|c|c|c|}
\hline \multirow[b]{2}{*}{ compd } & \multicolumn{5}{|c|}{$\mathrm{IC}_{50}(\mu \mathrm{M})^{a}$} \\
\hline & thrombin & chymotrypsin & kallikrein & urokinase & cathepsin D \\
\hline $5 b$ & $1.9 \pm 0.62$ & $0.066 \pm 0.019$ & $\mathrm{NA}^{b}$ & $6.6 \pm 2.7$ & NA \\
\hline $14 \mathrm{f}$ & $0.48 \pm 0.12$ & $0.040 \pm 0.012$ & NA & $1.5 \pm 0.65$ & NA \\
\hline $14 \mathrm{~g}$ & $0.082 \pm 0.033$ & $0.021 \pm 0.057$ & NA & $0.48 \pm 0.11$ & NA \\
\hline $20 \mathrm{a}$ & $0.31 \pm 0.059$ & $0.17 \pm 0.049$ & NA & $13.7 \pm 3.6$ & NA \\
\hline $14 \mathrm{~h}$ & $0.37 \pm 0.12$ & $0.046 \pm 0.003$ & NA & $25.3 \pm 6.2$ & NA \\
\hline $14 a$ & $0.83 \pm 0.14$ & $0.031 \pm 0.008$ & $11.2 \pm 2.6$ & $0.62 \pm 0.17$ & NA \\
\hline $14 \mathrm{~b}$ & $1.1 \pm 0.35$ & $0.015 \pm 0.004$ & NA & $0.44 \pm 0.13$ & NA \\
\hline 15 & $0.64 \pm 0.19$ & $0.038 \pm 0.012$ & NA & $0.31 \pm 0.018$ & NA \\
\hline $20 \mathrm{~b}$ & $0.039 \pm 0.011$ & $0.14 \pm 0.026$ & NA & $14.8 \pm 4.6$ & NA \\
\hline $20 \mathrm{f}$ & $0.16 \pm 0.035$ & $0.37 \pm 0.045$ & NA & NA & NA \\
\hline
\end{tabular}

${ }^{a}$ The $\mathrm{IC}_{50}$ values are presented as the mean $\pm \mathrm{SD}$ of three independent experiments. ${ }^{b} \mathrm{NA}$ : no inhibition activity was found at the highest concentration of compound tested $(50 \mu \mathrm{M})$. 


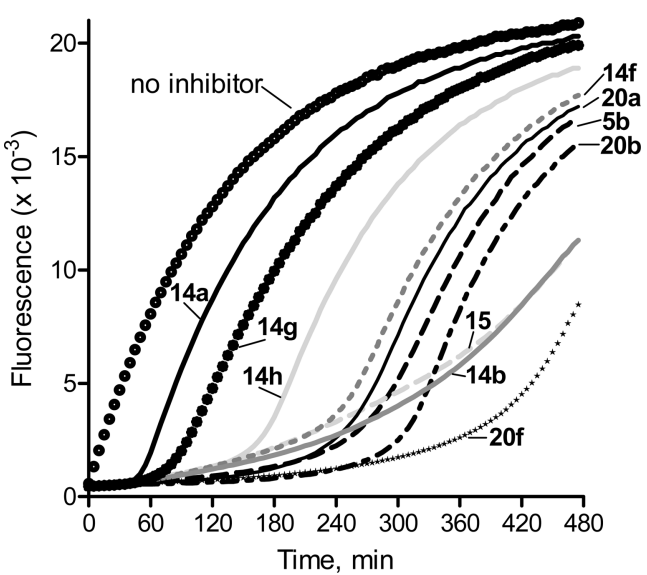

Figure 2. Evaluation of HNE inhibition by selected indazole derivatives over time. HNE was incubated with the indicated compounds at $5 \mu \mathrm{M}$ concentrations, and kinetic curves monitoring substrate cleavage catalyzed by HNE from 0 to $7 \mathrm{~h}$ are shown. Representative curves are from three independent experiments.

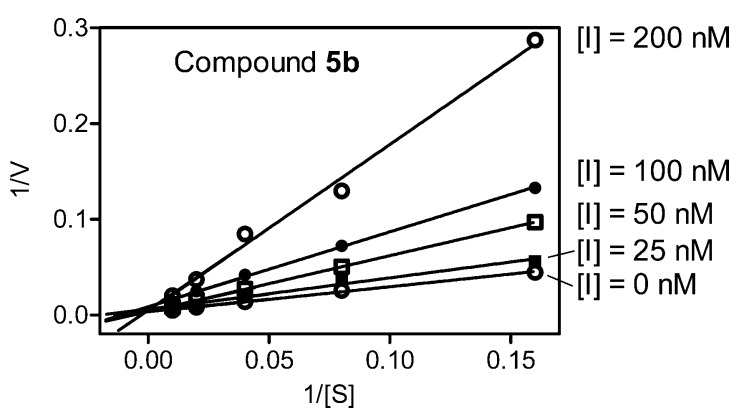

Figure 3. Kinetics of HNE inhibition by compound $\mathbf{5 b}$. Representative double-reciprocal Lineweaver-Burk plot from three independent experiments.

and $31 \mathbf{h}$ ) into the HNE binding site using the HNE structure from the Protein Data Bank (1HNE entry) where the enzyme is complexed with a peptide chloromethyl ketone inhibitor. ${ }^{41}$ Previously, we used an approach where the HNE conformation was adopted to be rigid, and a limited refinement of docking poses was undertaken with flexibility of only three residues (His57, Asp102, and Ser195) representing the catalytic triad of serine proteases. ${ }^{25,27}$ In the present study, we applied a more sophisticated methodology and performed docking with 42 flexible residues in the vicinity of the HNE binding site (see Experimental Section) using Molegro software.

The search area for docking was defined as a sphere $10 \AA$ in radius centered at the nitrogen atom of the 5-membered ring of the complexed inhibitor from the PDB file. This sphere embraced almost the entire peptide chloromethyl ketone inhibitor molecule and the nearest HNE residues, including the catalytic triad of His57, Asp102, and Ser195. The best docking poses obtained are located near the tail of the cocrystallized peptide chloromethyl ketone inhibitor (see in Figure 4 where the peptide and the pose of compound $\mathbf{5 b}$ are shown superimposed).

Analysis of the docking poses was performed to determine the distances $d_{1}-d_{3}$ and angle $\mathrm{O}($ Ser195) $\cdots \mathrm{C}=\mathrm{O} \quad(\alpha$, Supporting Information Figure 1S), important for the consideration of Michaelis complex formation and for easy proton transfer within the oxyanione hole. ${ }^{42-44}$ The geometric parameters of the lowest-energy enzyme-inhibitor complexes

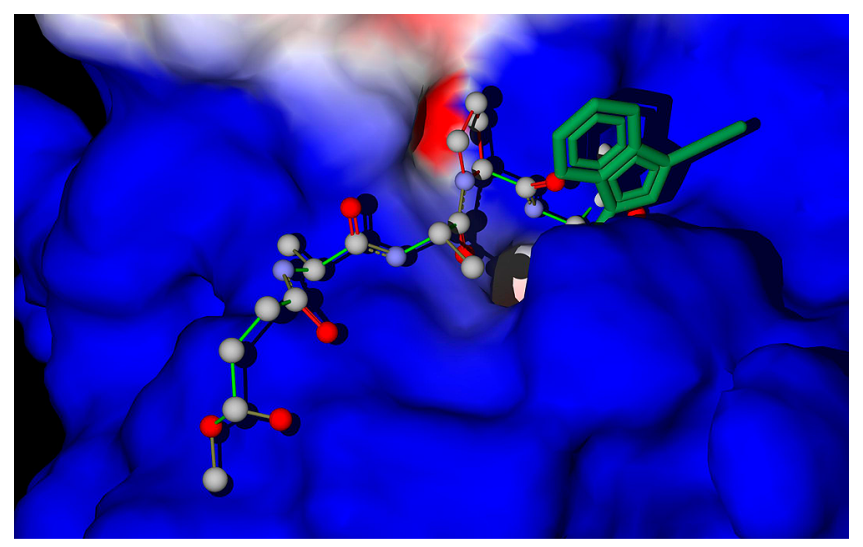

Figure 4. Superimposed docking poses of compound $\mathbf{5 b}$ (dark-green) and peptide chloromethyl ketone inhibitor. The peptide inhibitor is shown with a ball-stick rendering. The surface corresponds to the initial enzyme structure from the PDB file.

obtained by docking are presented in Table 6. Although the docking poses are not Michaelis complexes themselves, it is

Table 6. Biological Activities of HNE Inhibitors and Geometric Parameters of the Enzyme-Inhibitor Complexes Predicted by Docking

\begin{tabular}{ccccccc} 
compd & $\mathrm{IC}_{50}(\mu \mathrm{M})^{a}$ & $\alpha$ & $d_{1}$ & $d_{2}$ & $d_{3}$ & $L^{b}$ \\
\hline 5b & 0.007 & 119.3 & 3.448 & $2.181 ; 3.755$ & 3.142 & 5.323 \\
5d & 12.5 & 105.5 & 4.348 & $5.702 ; 5.844$ & 2.449 & 8.151 \\
$\mathbf{8}$ & NA & 169.4 & 4.590 & $1.796 ; 3.357$ & 3.272 & 5.068 \\
14f & 0.02 & 129.8 & 4.079 & $2.158 ; 3.749$ & 3.119 & 5.277 \\
26b & 0.08 & 75.5 & 3.874 & $1.730 ; 3.312$ & 2.753 & 4.483 \\
31h & 6.4 & 96.4 & 4.222 & $2.362 ; 3.959$ & 3.303 & 5.665
\end{tabular}

${ }^{a} \mathrm{HNE}$ inhibitory activity. ${ }^{b}$ Length of the channel for proton transfer calculated as $d_{3}+\min \left(d_{2}\right)$.

reasonable to regard their structures as approximations to the geometries of these complexes, keeping in mind that many residues were treated as flexible in the docking procedure. According to previous reports, ${ }^{42,43}$ it is optimal when the Michaelis complex formed with participation of an inhibitor's amido moiety has the ligand carbonyl carbon atom located 1.8-2.6 $\AA$ from the Ser195 hydroxyl oxygen (distance $d_{1}$ ), while the angle $\alpha$ is within $80-120^{\circ}$. As shown in Table 6, the highly active compounds $\mathbf{5 b}, \mathbf{1 4 f}$, and $\mathbf{2 6 b}$ in their best docking poses had shorter $d_{1}$ values than the less active inhibitors $\mathbf{5} \mathbf{d}$ and $31 \mathrm{~h}$ or inactive compound $\mathbf{8}$. Hence, the distance optimal for Michaelis complex is more attainable from these poses. Moreover, all active inhibitors were characterized by angle $\alpha$ in the optimal range $(\mathbf{5 b}, \mathbf{5 d}$, and $\mathbf{3 1 h})$ or close to this range (14f and 26b). On the other hand, angle $\alpha$ was too obtuse in the docking pose of inactive compound 8 (Table 6). A visual inspection of this pose (Supporting Information Figure S2) indicated that an optimal value of $\alpha$ is hardly reachable from the calculated binding mode of $\mathbf{8}$ because the molecule is anchored by strong $\mathrm{H}$-bonds formed between the oxymethyl group and backbone heteroatoms in Cys191 and Ser195. Thus, such an anchoring causes a very high energy barrier for reorienting 8 to form the Michaelis complex within the binding site.

The three residues, His57, Asp102, and Ser195, form a catalytic triad, which acts as general base and enhances nucleophilicity of Ser195 by the synchronous proton transfer from the OH group of Ser195 to Asp102 through the His57 
imidazole moiety. ${ }^{41,45,46}$ Conformational changes of the enzyme in the process of Michaelis complex formation can destroy the channel of proton transfer because of possible unfavorable orientation of the residues in the catalytic triad. To evaluate conditions for synchronous proton transfer, we have calculated an effective length $(L)$ of the channel as a sum of distances $d_{2}$ and $d_{3}$ (Supporting Information Figure S1). The most active compounds ( $\mathbf{5 b}, \mathbf{1 4 f}$, and $\mathbf{2 6 b}$ ) had shorter $L$ values than the moderately active inhibitors $5 \mathbf{d}$ and $3 \mathbf{~ h}$ (Table 6). Although a relatively low $L$ was obtained for inactive compound 8 , the main reason of its inactivity is the unfavorable positioning of the ligand due to $\mathrm{H}$-bond formation, as described above.

The results of this investigation, as well as those of our previous studies, ${ }^{25,27}$ show that HNE inhibitory activity strongly depends on the geometric characteristics of ligandenzyme complexes. The ability of a ligand to form a Michaelis complex and favorable conditions for proton transfer within the binding site affected inhibitor activity. Hence, both an inhibitor orientation with respect to Ser195 and the relative positioning of residues in the catalytic triad are important.

\section{CONCLUSIONS}

These results confirm that the $N$-benzoylindazole scaffold is an appropriate structure for development of potent HNE inhibitors and that, by maintaining a benzoyl substituent at $\mathrm{N}-1$, which is essential for activity, it is possible to increase the potency by inserting substituents at the phenyl ring of the indazole. In particular, the best results were obtained introducing nitro, bromine, or acylamino groups at position 5 , which resulted in corresponding HNE inhibitors with $\mathrm{IC}_{50}$ values of $12-50 \mathrm{nM}$. Furthermore, modifications at position 3 led to the most potent $\mathrm{HNE}$ inhibitor, $\mathbf{5 b}$, with $\mathrm{IC}_{50}=7 \mathrm{nM}$. Analysis of specificity showed that compounds $\mathbf{5 b}$ and $\mathbf{2 0 f}$ were relatively selective for HNE versus other proteases evaluated. Finally, molecular docking studies strongly suggested that the geometry of ligand-enzyme complexes was the main factor influencing interaction of inhibitors with the HNE binding site. Besides the ability of a compound to form a Michaelis complex, a suitable orientation of His57, Asp102, and Ser195 was also important for effective proton transfer from the oxyanione hole. Thus, the novel HNE inhibitors reported here represent potential leads for future optimization and in vivo studies.

\section{EXPERIMENTAL SECTION}

Chemistry. All melting points were determined on a Büchi apparatus and are uncorrected. ${ }^{1} \mathrm{H}$ NMR spectra were recorded with an Avance 400 instrument (Bruker Biospin Version 002 with SGU). Chemical shifts are reported in ppm, using the solvent as internal standard. Extracts were dried over $\mathrm{Na}_{2} \mathrm{SO}_{4}$, and the solvents were removed under reduced pressure. Merck F-254 commercial plates were used for analytical TLC to follow the course of reaction. Silica gel 60 (Merck 70-230 mesh) was used for column chromatography. Microanalyses were performed with a Perkin-Elmer 260 elemental analyzer for $\mathrm{C}, \mathrm{H}$, and $\mathrm{N}$, and the results were within $\pm 0.4 \%$ of the theoretical values unless otherwise stated. Reagents and starting materials were commercially available.

Acetic Acid $1 \mathrm{H}$-Indazol-3-yl Methyl Ester (2). A mixture of $\mathbf{1}^{30}$ $(0.2 \mathrm{mmol}), 1 \mathrm{~mL}$ of acetic acid, and $0.12 \mathrm{~mL}$ of conc $\mathrm{H}_{2} \mathrm{SO}_{4}$ was heated at $100{ }^{\circ} \mathrm{C}$ for $2 \mathrm{~h}$. After cooling, cold water was added and the mixture was extracted with ethyl acetate $(3 \times 10 \mathrm{~mL})$. Evaporation of the solvent resulted in compound 2 . Yield $=98 \%$; oil. ${ }^{1} \mathrm{H}$ NMR $\left(\mathrm{CDCl}_{3}\right) \delta 2.17\left(\mathrm{~s}, 3 \mathrm{H}, \mathrm{CH}_{3}\right), 5.60\left(\mathrm{~s}, 2 \mathrm{H}, \mathrm{CH}_{2}\right), 7.30(\mathrm{t}, 1 \mathrm{H}, \mathrm{Ar}, J=$ $8.4 \mathrm{~Hz}), 7.54(\mathrm{t}, 1 \mathrm{H}, \mathrm{Ar}, J=8.4 \mathrm{~Hz}), 7.64(\mathrm{~d}, 1 \mathrm{H}, \mathrm{Ar}, J=8.4 \mathrm{~Hz}), 7.88$ $(\mathrm{d}, 1 \mathrm{H}, \mathrm{Ar}, J=8.4 \mathrm{~Hz}$ ).
General Procedure for $5 \mathrm{a}-\mathrm{c}$ and 5 e. To a cooled $\left(0{ }^{\circ} \mathrm{C}\right)$ suspension of the appropriate substrate $2,3{ }^{28}$ or $4^{29}(0.42 \mathrm{mmol})$ in anhydrous $\mathrm{CH}_{2} \mathrm{Cl}_{2}(1-2 \mathrm{~mL})$, a catalytic amount of $\mathrm{Et}_{3} \mathrm{~N}(0.05 \mathrm{~mL})$ and the (substituted)-benzoyl chloride $(1.26 \mathrm{mmol})$ were added. The solution was stirred at $0{ }^{\circ} \mathrm{C}$ for $1-2 \mathrm{~h}$ and then for $1-3 \mathrm{~h}$ at room temperature. The precipitate was removed by suction, and the organic solvent was evaporated under vacuum. The residue was mixed in with ice-cold water $(20 \mathrm{~mL})$ and neutralized with $0.5 \mathrm{~N} \mathrm{NaOH}$, and the suspension was extracted with $\mathrm{CH}_{2} \mathrm{Cl}_{2}(3 \times 15 \mathrm{~mL})$. Evaporation of the solvent resulted in the final compounds $\mathbf{5 a}-\mathbf{c}$ and $\mathbf{5 d}$, which were purified by crystallization from ethanol (compounds $\mathbf{5 a}, \mathbf{b}$ ) or by column chromatography using cycloexane/ethyl acetate 2:1 (for $\mathbf{5 c}$ ) or toluene/ethyl acetate 9.5:0.5 (for 5e) as eluent.

1-Benzoyl-1H-Indazole-3-carbonitrile (5a). Yield $=35 \% ; \mathrm{mp}=$ 156-157 ${ }^{\circ} \mathrm{C}(\mathrm{EtOH}) .{ }^{1} \mathrm{H}$ NMR $\left(\mathrm{CDCl}_{3}\right) \delta 7.63-7.74(\mathrm{~m}, 4 \mathrm{H}, \mathrm{Ar})$, $7.88(\mathrm{t}, 1 \mathrm{H}, \mathrm{Ar}, J=8.0 \mathrm{~Hz}), 8.00-8.03(\mathrm{~m}, 2 \mathrm{H}, \mathrm{Ar}), 8.10(\mathrm{~d}, 1 \mathrm{H}, \mathrm{Ar}, J$ $=8.0 \mathrm{~Hz}), 8.52(\mathrm{~d}, 1 \mathrm{H}, \mathrm{Ar}, J=8.0 \mathrm{~Hz})$.

1-(3-Methylbenzoyl)-1H-indazole-3-carbonitrile (5b). Yield = $22 \% ; \mathrm{mp}=135-136{ }^{\circ} \mathrm{C}(\mathrm{EtOH}) .{ }^{1} \mathrm{H}$ NMR $\left(\mathrm{CDCl}_{3}\right) \delta 2.43(\mathrm{~s}, 3 \mathrm{H}$, $\left.\mathrm{CH}_{3}\right), 7.48-7.57(\mathrm{~m}, 2 \mathrm{H}, \mathrm{Ar}), 7.68(\mathrm{t}, 1 \mathrm{H}, \mathrm{Ar}, J=8.0 \mathrm{~Hz}), 7.81(\mathrm{~s}, 2 \mathrm{H}$, $\mathrm{Ar}), 7.87(\mathrm{t}, 1 \mathrm{H}, \mathrm{Ar}, J=8.4 \mathrm{~Hz}), 8.09(\mathrm{~d}, 1 \mathrm{H}, \mathrm{Ar}, J=8.0 \mathrm{~Hz}), 8.51$ (d, $1 \mathrm{H}, \mathrm{Ar}, J=8.4 \mathrm{~Hz})$.

1-Benzoyl-1H-indazole-3-carboxylic Acid Amide (5c). Yield = $10 \% ; \mathrm{mp}=204-206{ }^{\circ} \mathrm{C}(\mathrm{EtOH}) .{ }^{1} \mathrm{H}$ NMR $\left(\right.$ DMSO- $\left.d_{6}\right) 7.53-7.62$ (m, 3H, Ar), 7.69-7.76 (m, 2H, Ar), 7.84 (exch br s, 1H, NH N $^{2}, 7.94$ (exch br s, $1 \mathrm{H}, \mathrm{NH}_{2}$ ), 8.14 (d, $\left.2 \mathrm{H}, \mathrm{Ar}, J=7.2 \mathrm{~Hz}\right), 8.29$ (d, $1 \mathrm{H}, \mathrm{Ar}, J=$ $8.0 \mathrm{~Hz}), 8.47(\mathrm{~d}, 1 \mathrm{H}, \mathrm{Ar}, J=8.0 \mathrm{~Hz})$.

Acetic Acid 1-(3-Methylbenzoyl)-1H-indazol-3-yl Methyl Ester (5e). Yield $=22 \% ; \mathrm{mp}=135-136{ }^{\circ} \mathrm{C}(\mathrm{EtOH}) .{ }^{1} \mathrm{H} \mathrm{NMR}\left(\mathrm{CDCl}_{3}\right) \delta$ $2.16\left(\mathrm{~s}, 3 \mathrm{H}, \mathrm{Ph}-\mathrm{CH}_{3}\right), 2.48\left(\mathrm{~s}, 3 \mathrm{H}, \mathrm{COCH}_{3}\right), 5.50\left(\mathrm{~s}, 2 \mathrm{H}, \mathrm{CH}_{2}\right), 7.42-$ $7.47(\mathrm{~m}, 3 \mathrm{H}, \mathrm{Ar}), 7.66(\mathrm{t}, 1 \mathrm{H}, \mathrm{Ar}, J=8.4 \mathrm{~Hz}), 7.85(\mathrm{~d}, 1 \mathrm{H}, \mathrm{Ar}, J=8.0$ $\mathrm{Hz}), 7.89(\mathrm{~s}, 2 \mathrm{H}, \mathrm{Ar}), 8.58(\mathrm{~d}, 1 \mathrm{H}, \mathrm{Ar}, J=8.4 \mathrm{~Hz})$.

1-(3-Methylbenzoyl)-1H-indazole-3-carboxylic Acid Amide (5d). To a cooled $\left(-5\right.$ to $\left.-7{ }^{\circ} \mathrm{C}\right)$ suspension of $m$-toluic acid $(0.62$ $\mathrm{mmol})$ in anhydrous THF $(5 \mathrm{~mL}), 2.17 \mathrm{mmol}$ of $\mathrm{Et}_{3} \mathrm{~N}$ was added. The suspension was stirred for $30 \mathrm{~min}$, and after warming up to $0{ }^{\circ} \mathrm{C}$, ethyl chloroformate was added $(0.68 \mathrm{mmol})$. The mixture was stirred for 1 $\mathrm{h}$, and then $1.24 \mathrm{mmol}$ of $3^{28}$ was added. The reaction was carried out at room temperature for $12 \mathrm{~h}$, and evaporation of the solvent resulted in the desired final compound, which was purified by column chromatography (cycloexane/ethyl acetate gradient $4: 1$ to $3: 1$ ). Yield $=10 \% ; \mathrm{mp}=220{ }^{\circ} \mathrm{C} \operatorname{dec}(\mathrm{EtOH}) .{ }^{1} \mathrm{H}$ NMR $\left(\mathrm{CDCl}_{3}\right) \delta 2.33(\mathrm{~s}, 3 \mathrm{H}$, $\left.\mathrm{CH}_{3}\right), 6.98(\mathrm{t}, 1 \mathrm{H}, \mathrm{Ar}, J=7.6 \mathrm{~Hz}), 7.22(\mathrm{~d}, 1 \mathrm{H}, \mathrm{Ar}, J=8.0 \mathrm{~Hz}), 7.60(\mathrm{t}$, $1 \mathrm{H}, \mathrm{Ar}, J=8.0 \mathrm{~Hz}), 7.73(\mathrm{t}, 1 \mathrm{H}, \mathrm{Ar}, J=8.4 \mathrm{~Hz}), 7.83(\mathrm{~d}, 1 \mathrm{H}, \mathrm{Ar}, J=$ $8.0 \mathrm{~Hz}$ ), 7.93 (s, 1H, Ar), 8.55 (d, 2H, Ar, $J=8.4 \mathrm{~Hz}$ ), 10.81 (exch br s, $\left.2 \mathrm{H}, \mathrm{NH}_{2}\right)$.

3-(Tetrahydro-2H-pyran-2-yloxymethyl)-1H-indazole (6). To a mixture of a catalytic amount of ammonium cerium(IV) nitrate (CAN) in anhydrous $\mathrm{CH}_{3} \mathrm{CN}(2.5 \mathrm{~mL}), 0.53 \mathrm{mmol}$ of $1{ }^{30}$ and 0.53 mmol of 3,4 dihydro- $2 \mathrm{H}$-pyran (commercially available) were added, and the suspension was stirred at room temperature for $24 \mathrm{~h}$. After evaporation of the solvent, water was added $(20 \mathrm{~mL})$, the mixture was extracted with $\mathrm{CH}_{2} \mathrm{Cl}_{2}$, and the organic layer was evaporated in vacuo, resulting in crude 6 , which was purified by column chromatography using $\mathrm{CH}_{2} \mathrm{Cl}_{2} / \mathrm{CH}_{3} \mathrm{OH}$ 9.5:0.5 as eluent. Yield $=33 \%$; oil. ${ }^{1} \mathrm{H}$ NMR $\left(\mathrm{CDCl}_{3}\right) \delta 1.59-1.86\left(\mathrm{~m}, 6 \mathrm{H}, \mathrm{cC}_{5} \mathrm{H}_{9} \mathrm{O}\right), 3.60-3.78(\mathrm{~m}, 1 \mathrm{H}$, $\left.\mathrm{cC}_{5} \mathrm{H}_{9} \mathrm{O}\right), 3.90-4.05\left(\mathrm{~m}, 1 \mathrm{H}, \mathrm{cC}_{5} \mathrm{H}_{9} \mathrm{O}\right), 4.83(\mathrm{~s}, 1 \mathrm{H}, \mathrm{O}-\mathrm{CH}-\mathrm{O})$, 4.90-5.00 (m, $\left.1 \mathrm{H}, \mathrm{C}-\mathrm{CH}_{2}-\mathrm{O}\right), 5.15-5.22\left(\mathrm{~m}, 1 \mathrm{H}, \mathrm{C}-\mathrm{CH}_{2}-\mathrm{O}\right)$ 7.15-7.22 (m, 1H, Ar), 7.37-7.51 (m, 2H, Ar), 7.87-7.93 (m, $1 \mathrm{H}$, Ar), 10.62 (exch br s, $1 \mathrm{H}, \mathrm{NH}$ ).

3-(Tetrahydro-2H-pyran-2-yloxymethyl)-indazol-1-yl]-mtolyl-methanone (7). Compound 7 was obtained starting from intermediate 6 by reaction with $m$-toluoyl chloride, following the general procedure described for $\mathbf{5 a}-\mathbf{c}$ and $\mathbf{5 e}$. After evaporation of the solvent, the final compound was purified by column chromatography using toluene/ethyl acetate 9.5:0.5 as eluent. Yield $=50 \%$; oil. ${ }^{1} \mathrm{H}$ NMR $\left(\mathrm{CDCl}_{3}\right) \delta 1.60-1.88\left(\mathrm{~m}, 6 \mathrm{H}, \mathrm{cC}_{5} \mathrm{H}_{9} \mathrm{O}\right), 2.47\left(\mathrm{~s}, 3 \mathrm{H}, \mathrm{CH}_{3}\right)$, 3.55-3.65 (m, $\left.1 \mathrm{H}, \mathrm{cC}_{5} \mathrm{H}_{9} \mathrm{O}\right), 3.90-4.06\left(\mathrm{~m}, 1 \mathrm{H}, \mathrm{cC}_{5} \mathrm{H}_{9} \mathrm{O}\right), 4.84(\mathrm{~s}$, $1 \mathrm{H}, \mathrm{O}-\mathrm{CH}-\mathrm{O}), 4.90-4.98\left(\mathrm{~m}, 1 \mathrm{H}, \mathrm{C}-\mathrm{CH}_{2}-\mathrm{O}\right), 5.10-5.20(\mathrm{~m}, 1 \mathrm{H}$, 
$\mathrm{C}-\mathrm{CH}_{2}-\mathrm{O}$ ), 7.42 (s, 3H, Ar), 7.57-7.68 (m, 1H, Ar), 7.89 (s, $2 \mathrm{H}$, Ar), $7.90-8.00(\mathrm{~m}, 1 \mathrm{H}, \mathrm{Ar}), 8.52-8.61(\mathrm{~m}, 1 \mathrm{H}, \mathrm{Ar})$.

(3-Hydroxymethyl-indazol-1-yl)-m-tolylmethanone (8). A mixture of $7(0.09 \mathrm{mmol})$, trifluoroacetic acid $(0.28 \mathrm{~mL})$, and $\mathrm{CH}_{2} \mathrm{Cl}_{2}(1.72 \mathrm{~mL})$ was stirred at room temperature for $3 \mathrm{~h}$. Evaporation of the solvent resulted in compound 8, which was purified by column chromatography using $\mathrm{CH}_{2} \mathrm{Cl}_{2} / \mathrm{CH}_{3} \mathrm{OH}$ 9.9:0.1 as eluent. Yield $=87 \%$; oil. ${ }^{1} \mathrm{H}$ NMR $\left(\mathrm{CDCl}_{3}\right) \delta 2.20($ exch br s, $1 \mathrm{H}$, $\mathrm{OH}), 2.47$ (s, 3H, $\left.\mathrm{CH}_{3}\right), 5.08\left(\mathrm{~s}, 2 \mathrm{H}, \mathrm{CH}_{2} \mathrm{OH}\right) 7.44$ (s, 3H, Ar), 7.62 (m, 1H, Ar), 7.80-7.91 (m, 3H, Ar), 8.50-8.56 (m, 1H, Ar).

6-Nitro-1 $\mathrm{H}$-indazole-3-carboxylic Acid Ethyl Ester (12b). To a cooled and stirred solution of conc $\mathrm{H}_{2} \mathrm{SO}_{4}$ and conc $\mathrm{HNO}_{3}(1.5 \mathrm{~mL}$, $1: 1, \mathrm{v} / \mathrm{v}), 0.45 \mathrm{mmol}$ of $\mathbf{1 0}$ was slowly added, and the mixture was kept under stirring at $0{ }^{\circ} \mathrm{C}$ for $10 \mathrm{~min}$. After dilution with ice-cold water, the precipitate was filtered and washed with water $(10-20 \mathrm{~mL})$. Finally, compound $\mathbf{1 2 b}$ was purified by column chromatography using cycloexane/ethyl acetate 4:1 as eluent. Yield $=10 \% ; \mathrm{mp}=120-121$ ${ }^{\circ} \mathrm{C}(\mathrm{EtOH}) .{ }^{1} \mathrm{H}$ NMR $\left(\mathrm{CDCl}_{3}\right) \delta 1.54\left(\mathrm{t}, 3 \mathrm{H}, \mathrm{CH}_{3}, J=7.2 \mathrm{~Hz}\right), 4.64$ $\left(\mathrm{q}, 2 \mathrm{H}, \mathrm{CH}_{2}, J=7.2 \mathrm{~Hz}\right), 8.46$ (d, $\left.1 \mathrm{H}, \mathrm{Ar}, J=9.6 \mathrm{~Hz}\right), 8.73(\mathrm{~d}, 1 \mathrm{H}, \mathrm{Ar}$, $J=9.2 \mathrm{~Hz}$ ), 9.27 (s, 1H, Ar), 11,67 (exch br s, 1H, NH).

General Procedures for $14 a, b$, and 14f. Compounds 14a,b and $14 \mathrm{f}$ were obtained starting from 11a and $11 \mathrm{~b}$, respectively, following the general procedure described for $5 \mathbf{a}-\mathbf{c}$ and 5 e. For compound $14 a$, after dilution with cold water and neutralization with $0.5 \mathrm{~N} \mathrm{NaOH}$, the precipitate was filtered off and purified by crystallization from ethanol. For compound $\mathbf{1 4 b}$ and $14 \mathrm{e}$, after dilution and neutralization with $\mathrm{NaOH}$, the suspension was extracted with $\mathrm{CH}_{2} \mathrm{Cl}_{2}(3 \times 15 \mathrm{~mL})$, and evaporation of the solvent resulted in the final compounds, which were recrystallized from ethanol.

1-Benzoyl-5-nitro-1H-indazole-3-carboxylic Acid Methyl Ester (14a). Yield $=62 \% ; \mathrm{mp}=156-157{ }^{\circ} \mathrm{C}(\mathrm{EtOH}) .{ }^{1} \mathrm{H}$ NMR $\left(\mathrm{CDCl}_{3}\right)$ $\delta 4.13\left(\mathrm{~s}, 3 \mathrm{H}, \mathrm{CH}_{3}\right), 7.60(\mathrm{t}, 2 \mathrm{H}, \mathrm{Ar}, J=8.0 \mathrm{~Hz}), 7.72(\mathrm{t}, 1 \mathrm{H}, \mathrm{Ar}, J=$ $8.0 \mathrm{~Hz}), 8.19(\mathrm{~d}, 2 \mathrm{H}, \mathrm{Ar}, J=8.0 \mathrm{~Hz}), 8.56(\mathrm{~d}, 1 \mathrm{H}, \mathrm{Ar}, J=7.2 \mathrm{~Hz}), 8.73$ $(\mathrm{d}, 1 \mathrm{H}, \mathrm{Ar}, J=9.2 \mathrm{~Hz}), 9.23(\mathrm{~d}, 1 \mathrm{H}, \mathrm{Ar}, J=2.0 \mathrm{~Hz}$ ).

1-(3-Methylbenzoyl)-5-nitro-1H-indazole-3-carboxylic Acid Methyl Ester (14b). Yield $=52 \% ; \mathrm{mp}=180-181{ }^{\circ} \mathrm{C}(\mathrm{EtOH}) .{ }^{1} \mathrm{H}$ NMR $\left(\mathrm{CDCl}_{3}\right) \delta 2.50\left(\mathrm{~s}, 3 \mathrm{H}, \mathrm{CH}_{3}-\mathrm{Ph}\right), 4.13\left(\mathrm{~s}, 3 \mathrm{H}, \mathrm{OCH}_{3}\right), 7.47-$ $7.53(\mathrm{~m}, 2 \mathrm{H}, \mathrm{Ar}), 7.90$ (d, 2H, Ar, $J=7.2 \mathrm{~Hz}$ ), 8.55 (d, 1H, Ar, $J=5.2$ $\mathrm{Hz}), 8.71(\mathrm{~d}, 1 \mathrm{H}, \mathrm{Ar}, J=9.2 \mathrm{~Hz}), 9.22(\mathrm{~d}, 1 \mathrm{H}, \mathrm{Ar}, J=2.0 \mathrm{~Hz})$.

1-(3-Methylbenzoyl)-5-nitro-1H-indazole-3-carboxylic Acid Ethyl Ester (14f). Yield $=76 \% ; \mathrm{mp}=150-153{ }^{\circ} \mathrm{C}(\mathrm{EtOH}) .{ }^{1} \mathrm{H}$ NMR $\left(\mathrm{CDCl}_{3}\right) \delta 1.54\left(\mathrm{t}, 3 \mathrm{H}, \mathrm{CH}_{2} \mathrm{CH}_{3}, J=7.2 \mathrm{~Hz}\right), 2.50\left(\mathrm{~s}, 3 \mathrm{H}, \mathrm{Ph}-\mathrm{CH}_{3}\right)$, $4.62\left(\mathrm{q}, 2 \mathrm{H}, \mathrm{CH}_{2} \mathrm{CH}_{3}, J=7.2 \mathrm{~Hz}\right.$ ), 7.47-7.54 (m, $\left.2 \mathrm{H}, \mathrm{Ar}\right), 7.98$ (s, $2 \mathrm{H}, \mathrm{Ar}), 8.54(\mathrm{~d}, 1 \mathrm{H}, \mathrm{Ar}, J=7.2 \mathrm{~Hz}), 8.71(\mathrm{~d}, 1 \mathrm{H}, \mathrm{Ar}, J=9.2 \mathrm{~Hz}), 9.22$ (d, $1 \mathrm{H}, \mathrm{Ar}, J=2.0 \mathrm{~Hz}$ ).

General Procedures for $14 \mathrm{c}, \mathrm{d}$, and $14 \mathrm{~g}, \mathrm{~h}$. The appropriate (hetero)arylcarboxylic acids $(0.90 \mathrm{mmol})$ were dissolved in $2 \mathrm{~mL}$ of $\mathrm{SOCl}_{2}$ and heated at $80-90{ }^{\circ} \mathrm{C}$ for $1 \mathrm{~h}$. After cooling, excess $\mathrm{SOCl}_{2}$ was removed under vacuum and the residue was dissolved in $3.5 \mathrm{~mL}$ of anhydrous toluene. A solution of $11 \mathbf{a}^{32}$ or $11 \mathbf{b}^{32}(0.45 \mathrm{mmol})$ and $\mathrm{Et}_{3} \mathrm{~N}(0.50 \mathrm{mmol})$ in anhydrous toluene $(3.5 \mathrm{~mL})$ was added to this mixture, and it was stirred at $110{ }^{\circ} \mathrm{C}$ for $3-6 \mathrm{~h}$. After cooling, the precipitate was removed by filtration, and the organic solvent was evaporated under vacuum. Addition of cold water to the residue and neutralization with $0.5 \mathrm{~N} \mathrm{NaOH}$ resulted in the final compounds. Compounds $14 \mathrm{c}, 14 \mathrm{~g}$, and $14 \mathrm{~h}$ were recovered by suction and recrystallized from ethanol, while the crude $14 \mathrm{~d}$ was recovered by extraction with ethyl acetate $(3 \times 15 \mathrm{~mL})$ and evaporation of the solvent. Compound $\mathbf{1 4 d}$ was finally crystallized from ethanol.

1-(3-Methoxybenzoyl)-5-nitro-1H-indazole-3-carboxylic Acid Methyl Ester (14c). Yield $=56 \% ; \mathrm{mp}=151-152{ }^{\circ} \mathrm{C}(\mathrm{EtOH}) .{ }^{1} \mathrm{H}$ NMR $\left(\mathrm{CDCl}_{3}\right) \delta 3.93\left(\mathrm{~s}, 3 \mathrm{H}, \mathrm{Ph}-\mathrm{OCH}_{3}\right), 4.13\left(\mathrm{~s}, 3 \mathrm{H}, \mathrm{COOCH}_{3}\right)$, $7.25(\mathrm{dd}, 1 \mathrm{H}, \mathrm{Ar}, J=2.4 \mathrm{~Hz}, J=5.6 \mathrm{~Hz}), 7.50(\mathrm{t}, 1 \mathrm{H}, \mathrm{Ar}, J=8.0 \mathrm{~Hz})$, 7.71 (s, 1H, Ar), 7.78 (d, $1 \mathrm{H}, \mathrm{Ar}, J=7,6 \mathrm{~Hz}), 8.56$ (dd, $1 \mathrm{H}, \mathrm{Ar}, J=2.0$ $\mathrm{Hz}, J=7.2 \mathrm{~Hz}), 8.72(\mathrm{~d}, 1 \mathrm{H}, \mathrm{Ar}, J=9.2 \mathrm{~Hz}), 9.22(\mathrm{~d}, 1 \mathrm{H}, \mathrm{Ar}, J=2.0$ $\mathrm{Hz}$ ).

5-Nitro-1-(thiophene-3-carbonyl)-1H-indazole-3-carboxylic Acid Methyl Ester (14d). Yield $=54 \% ; \mathrm{mp}=193-194{ }^{\circ} \mathrm{C}(\mathrm{EtOH}) .{ }^{1} \mathrm{H}$ NMR $\left(\mathrm{CDCl}_{3}\right) \delta 4.17\left(\mathrm{~s}, 3 \mathrm{H}, \mathrm{CH}_{3}\right), 7.47(\mathrm{~s}, 1 \mathrm{H}, \mathrm{Ar}), 8.02(\mathrm{~m}, 1 \mathrm{H}$,
$\mathrm{Ar}), 8.54(\mathrm{~d}, 1 \mathrm{H}, \mathrm{Ar}, J=9.2 \mathrm{~Hz}), 8.77(\mathrm{~d}, 1 \mathrm{H}, \mathrm{Ar}, J=9.2 \mathrm{~Hz}), 9.00(\mathrm{~s}$, $1 \mathrm{H}, \mathrm{Ar}), 9,21(\mathrm{~s}, 1 \mathrm{H}, \mathrm{Ar})$.

1-(3-Methoxybenzoyl)-5-nitro-1H-indazole-3-carboxylic Acid Ethyl Ester (14g). Yield $=54 \% ; \mathrm{mp}=193-194{ }^{\circ} \mathrm{C}(\mathrm{EtOH}) .{ }^{1} \mathrm{H}$ NMR $\left(\mathrm{CDCl}_{3}\right) \delta 1.53\left(\mathrm{t}, 3 \mathrm{H}, \mathrm{CH}_{2} \mathrm{CH}_{3}, J=7.2 \mathrm{~Hz}\right), 3.93(\mathrm{~s}, 3 \mathrm{H}$, $\left.\mathrm{OCH}_{3}\right), 4.61\left(\mathrm{q}, 2 \mathrm{H}, \mathrm{CH}_{2}, J=7.2 \mathrm{~Hz}\right), 7.25(\mathrm{~d}, 1 \mathrm{H}, \mathrm{Ar}, J=5.6 \mathrm{~Hz})$, $7.50(\mathrm{t}, 1 \mathrm{H}, \mathrm{Ar}, J=8.0 \mathrm{~Hz}), 7.74(\mathrm{~s}, 1 \mathrm{H}, \mathrm{Ar}), 7.80(\mathrm{~d}, 1 \mathrm{H}, \mathrm{Ar}, J=8.0$ $\mathrm{Hz}), 8.55(\mathrm{~d}, 1 \mathrm{H}, \mathrm{Ar}, J=7.2 \mathrm{~Hz}), 8.72(\mathrm{~d}, 1 \mathrm{H}, \mathrm{Ar}, J=9.2 \mathrm{~Hz}), 9,22(\mathrm{~s}$, $1 \mathrm{H}, \mathrm{Ar})$.

5-Nitro-1-(thiophene-3-carbonyl)-1H-indazole-3-carboxylic Acid Ethyl Ester (14h). Yield $=48 \%$; $\mathrm{mp}=156-159{ }^{\circ} \mathrm{C}(\mathrm{EtOH}) .{ }^{1} \mathrm{H}$ NMR $\left(\mathrm{CDCl}_{3}\right) \delta 1.53\left(\mathrm{t}, 3 \mathrm{H}, \mathrm{CH}_{3}, J=7.2 \mathrm{~Hz}\right), 4.65\left(\mathrm{q}, 2 \mathrm{H}, \mathrm{CH}_{2}, J=7.2\right.$ $\mathrm{Hz}), 7.43-7.49$ (m, $1 \mathrm{H}, \mathrm{Ar}), 8.02(\mathrm{~d}, 1 \mathrm{H}, \mathrm{Ar}, J=5.2 \mathrm{~Hz}), 8.53$ (d, $1 \mathrm{H}$, $\mathrm{Ar}, J=7.2 \mathrm{~Hz}), 8.76(\mathrm{~d}, 1 \mathrm{H}, \mathrm{Ar}, J=9.2 \mathrm{~Hz}), 9.01(\mathrm{~d}, 1 \mathrm{H}, \mathrm{Ar}, J=1.6$ $\mathrm{Hz}), 9.2(\mathrm{~m}, 1 \mathrm{H}, \mathrm{Ar})$.

General Procedures for 15 and 16. Compounds 15 and 16 were obtained starting from compounds $12 \mathrm{a}^{33}$ and $13^{34}$ following the same procedure described for $\mathbf{5 a - c}$ and $\mathbf{5 e}$. After dilution with cold water and neutralization with $0.5 \mathrm{~N} \mathrm{NaOH}$, the suspension was extracted with $\mathrm{CH}_{2} \mathrm{Cl}_{2}(3 \times 15 \mathrm{~mL})$. Evaporation of the solvent resulted in the final compounds, which were purified by column chromatography using cyclohexane/ethyl acetate 4:1 as eluent.

1-(3-Methylbenzoyl)-6-nitro-1H-indazole-3-carboxylic Acid Methyl Ester (15). Yield $=5 \%$; $\mathrm{mp}=180-181{ }^{\circ} \mathrm{C}(\mathrm{EtOH}) .{ }^{1} \mathrm{H}$ $\operatorname{NMR}\left(\mathrm{CDCl}_{3}\right) \delta 2.50\left(\mathrm{~s}, 3 \mathrm{H}, \mathrm{CH}_{3}-\mathrm{Ph}\right), 4.13\left(\mathrm{~s}, 3 \mathrm{H}, \mathrm{CH}_{3}\right), 7.47-7.54$ (m, 2H, Ar), 7.94-7.99 (m, 2H, Ar), 8.55 (d, 1H, Ar, J=9.2 Hz), 8.71 (d, $1 \mathrm{H}, \mathrm{Ar}, J=7.2 \mathrm{~Hz}), 9.22(\mathrm{~m}, 1 \mathrm{H}, \mathrm{Ar})$.

1-(3-Methylbenzoyl)-7-nitro-1H-indazole-3-carboxylic Acid Methyl Ester (16). Yield $=17 \% ; \mathrm{mp}=118-119{ }^{\circ} \mathrm{C}(\mathrm{EtOH}) .{ }^{1} \mathrm{H}$ $\operatorname{NMR}\left(\mathrm{CDCl}_{3}\right) \delta 1.50\left(\mathrm{t}, 3 \mathrm{H}, \mathrm{CH}_{2} \mathrm{CH}_{3}, J=7.2 \mathrm{~Hz}\right), 2.48(\mathrm{~s}, 3 \mathrm{H}, \mathrm{Ph}-$ $\left.\mathrm{CH}_{3}\right), 4.56\left(\mathrm{q}, 2 \mathrm{H}, \mathrm{CH}_{2}, J=7.2 \mathrm{~Hz}\right), 7.49-7.56(\mathrm{~m}, 2 \mathrm{H}, \mathrm{Ar}), 7.65(\mathrm{t}$, $1 \mathrm{H}, \mathrm{Ar}, J=8.0 \mathrm{~Hz}$ ), 7.99 (s, 2H, Ar), $8.23(\mathrm{~d}, 1 \mathrm{H}, \mathrm{Ar}, J=8.0 \mathrm{~Hz}), 8.66$ (d, $1 \mathrm{H}, \mathrm{Ar}, J=8.0 \mathrm{~Hz}$ ).

5-Amino-1-(3-methylbenzoyl)-1H-indazole-3-carboxylic Acid Ethyl Ester (17). Compound $\mathbf{1 4 f}(0.31 \mathrm{mmol})$ was subjected to catalytic reduction in EtOH $(6 \mathrm{~mL})$ for $2 \mathrm{~h}$ with a Parr instrument using $70 \mathrm{mg}$ of $10 \% \mathrm{Pd} / \mathrm{C}$ as catalyst and the pressure kept constant at 30 psig. The catalyst was filtered off, and the solvent was evaporated under vacuum, resulting in the final compound, which was purified by crystallization from ethanol. Yield $=30 \% ; \mathrm{mp}=131-133{ }^{\circ} \mathrm{C}(\mathrm{EtOH})$. ${ }^{1} \mathrm{H}$ NMR $\left(\mathrm{CDCl}_{3}\right) \delta 1.48\left(\mathrm{t}, 3 \mathrm{H}, \mathrm{CH}_{2} \mathrm{CH}_{3}, J=7.2 \mathrm{~Hz}\right), 2.47(\mathrm{~s}, 3 \mathrm{H}$, $\mathrm{Ph}-\mathrm{CH}_{3}$ ), 3.94 (exch br s, $\left.2 \mathrm{H}, \mathrm{NH}_{2}\right), 4.52\left(\mathrm{q}, 2 \mathrm{H}, \mathrm{CH}_{2} J=7.2 \mathrm{~Hz}\right.$ ), 7.05 (dd, $1 \mathrm{H}, \mathrm{Ar}, J=2.4 \mathrm{~Hz}, J=6.4 \mathrm{~Hz}$ ), $7.40-7.46(\mathrm{~m}, 2 \mathrm{H}, \mathrm{Ar}), 7.47$ $(\mathrm{d}, 1 \mathrm{H}, \mathrm{Ar}, J=2.4 \mathrm{~Hz}), 7.94(\mathrm{~s}, 2 \mathrm{H}, \mathrm{Ar}), 8.36(\mathrm{~d}, 1 \mathrm{H}, \mathrm{Ar}, J=8.8 \mathrm{~Hz})$.

General Procedures for 18 and 19. A mixture of $0.31 \mathrm{mmol}$ of 17, $0.68 \mathrm{mmol}$ of $\mathrm{K}_{2} \mathrm{CO}_{3}$, and $0.54 \mathrm{mmol}$ of $\mathrm{CH}_{3} \mathrm{I}$ in $1 \mathrm{~mL}$ of anhydrous DMF was stirred at $50{ }^{\circ} \mathrm{C}$ for $3 \mathrm{~h}$. After cooling, ice-cold water was added $(10-15 \mathrm{~mL})$, and the suspension was extracted with $\mathrm{CH}_{2} \mathrm{Cl}_{2}(3 \times 15 \mathrm{~mL})$. The organic layer was evaporated in vacuo, and the residue was purified by flash column chromatography using cyclohexane/ethyl acetate 3:1 as eluent.

5-Methylamino-1-(3-methylbenzoyl)-1H-indazole-3-carboxylic Acid Ethyl Ester (18). Yield $=34 \%$; $\mathrm{mp}=152-154{ }^{\circ} \mathrm{C}(\mathrm{EtOH}) .{ }^{1} \mathrm{H}$ $\operatorname{NMR}\left(\mathrm{CDCl}_{3}\right) \delta 1.49\left(\mathrm{t}, 3 \mathrm{H}, \mathrm{CH}_{2} \mathrm{CH}_{3}, J=7.2 \mathrm{~Hz}\right), 2.47(\mathrm{~s}, 3 \mathrm{H}, \mathrm{Ph}-$ $\left.\mathrm{CH}_{3}\right), 2.98\left(\mathrm{~s}, 3 \mathrm{H}, \mathrm{NCH}_{3}\right), 4.02($ exch br s, $1 \mathrm{H}, \mathrm{NH}), 4.53(\mathrm{q}, 2 \mathrm{H}$, $\mathrm{CH}_{2}, J=7.2 \mathrm{~Hz}$ ), 6.99 (d, $\left.1 \mathrm{H}, \mathrm{Ar}, J=6.4 \mathrm{~Hz}\right), 7.30(\mathrm{~m}, 1 \mathrm{H}, \mathrm{Ar}), 7.40-$ $7.47(\mathrm{~m}, 2 \mathrm{H}, \mathrm{Ar}), 7.96$ (s, 2H, Ar), 8.35 (d, $1 \mathrm{H}, \mathrm{Ar}, J=9.2 \mathrm{~Hz})$.

5-Dimethylamino-1-(3-methylbenzoyl)-1H-indazole-3-carboxylic Acid Ethyl Ester (19). Yield $=28 \%$; $\mathrm{mp}=114-116{ }^{\circ} \mathrm{C}(\mathrm{EtOH}) .{ }^{1} \mathrm{H}$ NMR $\left(\mathrm{CDCl}_{3}\right) \delta 1.49\left(\mathrm{t}, 3 \mathrm{H}, \mathrm{CH}_{2} \mathrm{CH}_{3}, J=7.2 \mathrm{~Hz}\right), 2.47(\mathrm{~s}, 3 \mathrm{H}, \mathrm{Ph}-$ $\left.\mathrm{CH}_{3}\right), 3.09\left(\mathrm{~s}, 6 \mathrm{H}, \mathrm{N}\left(\mathrm{CH}_{3}\right)_{2}\right), 4.53\left(\mathrm{q}, 2 \mathrm{H}, \mathrm{CH}_{2}, J=7.2 \mathrm{~Hz}\right), 7.21(\mathrm{~d}$, $1 \mathrm{H}, J=6.4 \mathrm{~Hz}$ ), 7.40-7.48 (m, 3H, Ar), 7.97 (s, 2H, Ar), 8.41 (d, $1 \mathrm{H}$, Ar, $J=9.2 \mathrm{~Hz}$ ).

General Procedures for $20 \mathrm{a}-\mathrm{f}$. To a cooled $\left(0^{\circ} \mathrm{C}\right)$ suspension of $17(0.31 \mathrm{mmol})$ in anhydrous $\mathrm{CH}_{2} \mathrm{Cl}_{2}(2 \mathrm{~mL})$, a catalytic amount of $\mathrm{Et}_{3} \mathrm{~N}$ and $0.93 \mathrm{mmol}$ of the appropriate (cyclo)alkylcarbonyl or benzoylchloride were added. The mixture was stirred at $0{ }^{\circ} \mathrm{C}$ for $2 \mathrm{~h}$ and then at room temperature for $2 \mathrm{~h}$. Finally, the precipitates were recovered by vacuum filtration and recrystallized with ethanol.

5-Acetylamino-1-(3-methylbenzoyl)-1H-indazole-3-carboxylic Acid Ethyl Ester (20a). Yield = 27\%; mp $=155-158{ }^{\circ} \mathrm{C}(\mathrm{EtOH}) .{ }^{1} \mathrm{H}$ 
NMR (DMSO- $\left.d_{6}\right) \delta 1.39\left(\mathrm{t}, 3 \mathrm{H}, \mathrm{CH}_{2} \mathrm{CH}_{3}, J=7.2 \mathrm{~Hz}\right), 2.12(\mathrm{~s}, 3 \mathrm{H}$, $\left.\mathrm{COCH}_{3}\right), 2.43\left(\mathrm{~s}, 3 \mathrm{H}, \mathrm{Ph}-\mathrm{CH}_{3}\right), 4.44\left(\mathrm{q}, 2 \mathrm{H}, \mathrm{CH}_{2}, \mathrm{~J}=7.2 \mathrm{~Hz}\right), 7.49-$ 7.57 (m, 2H, Ar), 7.80-7.86 (m, 3H, Ar), 8.38 (d, 1H, Ar, J = 9.2 Hz), 8.65 (s, 1H, Ar), 10.32 (exch br s, 1H, NH).

1-(3-Methylbenzoyl)-5-propionylamino-1H-indazole-3-carboxylic Acid Ethyl Ester (20b). Yield = 95\%; mp $=116-119{ }^{\circ} \mathrm{C}(\mathrm{EtOH}) .{ }^{1} \mathrm{H}$ $\operatorname{NMR}\left(\mathrm{CDCl}_{3}\right) \delta 1.32\left(\mathrm{t}, 3 \mathrm{H}, \mathrm{COCH}_{2} \mathrm{CH}_{3}, J=7.2 \mathrm{~Hz}\right), 1.51(\mathrm{t}, 3 \mathrm{H}$, $\left.\mathrm{OCH}_{2} \mathrm{CH}_{3}, J=7.2 \mathrm{~Hz}\right), 2.47\left(\mathrm{~s}, 3 \mathrm{H}, \mathrm{Ph}-\mathrm{CH}_{3}\right), 2.51(\mathrm{q}, 2 \mathrm{H}$, $\mathrm{COCH}_{2} \mathrm{CH}_{3}, J=7.2 \mathrm{~Hz}$ ), $4.55\left(\mathrm{q}, 2 \mathrm{H}, \mathrm{OCH}_{2} \mathrm{CH}_{3}, J=7.2 \mathrm{~Hz}\right), 7.42-$ $7.48(\mathrm{~m}, 3 \mathrm{H}, \mathrm{Ar}), 7.83$ (d, 1H, Ar, $J=9.2 \mathrm{~Hz}$ ), 7.95 (s, 2H, Ar), 8.46 (exch br s, 1H, NH), 8.51 (d, $1 \mathrm{H}, \mathrm{Ar}, J=9.2 \mathrm{~Hz}$ ).

5-Butyrylamino-1-(3-methylbenzoyl)-1H-indazole-3-carboxylic Acid Ethyl Ester (20c). Yield $=72 \%$; $\mathrm{mp}=122-125{ }^{\circ} \mathrm{C}(\mathrm{EtOH}) .{ }^{1} \mathrm{H}$ NMR $\left(\mathrm{CDCl}_{3}\right) \delta 1.07\left(\mathrm{t}, 3 \mathrm{H}, \mathrm{CH}_{2} \mathrm{CH}_{2} \mathrm{CH}_{3}, J=7.2 \mathrm{~Hz}\right), 1.51(\mathrm{t}, 3 \mathrm{H}$, $\left.\mathrm{OCH}_{2} \mathrm{CH}_{3}, J=7.2 \mathrm{~Hz}\right), 1.84\left(\mathrm{~m}, 2 \mathrm{H}, \mathrm{CH}_{2} \mathrm{CH}_{2} \mathrm{CH}_{3}, J=7.2 \mathrm{~Hz}\right), 2.43$ $\left(\mathrm{t}, 2 \mathrm{H}, \mathrm{COCH}_{2}, J=7.2 \mathrm{~Hz}\right), 2.47\left(\mathrm{~s}, 3 \mathrm{H}, \mathrm{Ph}-\mathrm{CH}_{3}\right), 4.54(\mathrm{q}, 2 \mathrm{H}$, $\mathrm{OCH}_{2} \mathrm{CH}_{3}, J=7.2 \mathrm{~Hz}$ ), 7.37 (s, $\left.1 \mathrm{H}, \mathrm{Ar}\right), 7.42-7.48(\mathrm{~m}, 2 \mathrm{H}, \mathrm{Ar}), 7.82$ (d, $1 \mathrm{H}, \mathrm{Ar}, J=8.8 \mathrm{~Hz}), 7.96(\mathrm{~s}, 2 \mathrm{H}, \mathrm{Ar}), 8.46($ exch br s, $1 \mathrm{H}, \mathrm{NH})$, $8.51(\mathrm{~d}, 1 \mathrm{H}, \mathrm{Ar}, J=8.8 \mathrm{~Hz})$.

5-Benzoylamino-1-(3-methylbenzoyl)- $1 \mathrm{H}$-indazole-3-carboxylic Acid Ethyl Ester (20d). Yield $=78 \%$; $\mathrm{mp}=196-198{ }^{\circ} \mathrm{C}(\mathrm{EtOH}) .{ }^{1} \mathrm{H}$ NMR $\left(\mathrm{CDCl}_{3}\right) \delta 1.52\left(\mathrm{t}, 3 \mathrm{H}, \mathrm{CH}_{2} \mathrm{CH}_{3}, J=7.2 \mathrm{~Hz}\right), 2.48(\mathrm{~s}, 3 \mathrm{H}, \mathrm{Ph}-$ $\mathrm{CH}_{3}$ ), 4.55 (q, $2 \mathrm{H}, \mathrm{CH}_{2}, \mathrm{~J}=7.2 \mathrm{~Hz}$ ), 7.42-7.47 (m, 2H, Ar), 7.557.60 (m, 3H, Ar), 7.94-8.00 (m, 5H, Ar), 8.04 (exch br s, $1 \mathrm{H}, \mathrm{NH}$ ), $8.58(\mathrm{~d}, 2 \mathrm{H}, \mathrm{Ar}, J=9.2)$.

5-(Cyclohexanecarbonylamino)-1-(3-methylbenzoyl)-1H-indazole-3-carboxylic Acid Ethyl Ester (20e). Yield = 64\%; $\mathrm{mp}=189-191$ ${ }^{\circ} \mathrm{C}(\mathrm{EtOH}) .{ }^{1} \mathrm{H}$ NMR $\left(\mathrm{CDCl}_{3}\right) \delta 1.29-1.39\left(\mathrm{~m}, 3 \mathrm{H}, \mathrm{cC}_{6} \mathrm{H}_{11}\right), 1.51(\mathrm{t}$, $\left.3 \mathrm{H}, \mathrm{CH}_{2} \mathrm{CH}_{3}, J=7.2 \mathrm{~Hz}\right), 1.63\left(\mathrm{t}, 2 \mathrm{H}, \mathrm{cC}_{6} \mathrm{H}_{11}, J=5.6 \mathrm{~Hz}\right), 1.70-1.80$ $\left(\mathrm{m}, 1 \mathrm{H}, \mathrm{cC}_{6} \mathrm{H}_{11}\right), 1.85-1.95\left(\mathrm{~m}, 2 \mathrm{H}, \mathrm{cC}_{6} \mathrm{H}_{11}\right), 2.00-2.2 .05(\mathrm{~m}, 2 \mathrm{H}$, $\left.\mathrm{cC}_{6} \mathrm{H}_{11}\right), 2.28-2.38\left(\mathrm{~m}, 1 \mathrm{H}, \mathrm{cC}_{6} \mathrm{H}_{11}\right), 2.48\left(\mathrm{~s}, 3 \mathrm{H}, \mathrm{Ph}-\mathrm{CH}_{3}\right), 4.55(\mathrm{q}$, $\left.2 \mathrm{H}, \mathrm{CH}_{2} \mathrm{CH}_{3}, J=7.2 \mathrm{~Hz}\right), 7.32-7.40(\mathrm{~m}, 1 \mathrm{H}, \mathrm{Ar}), 7.40-7.46(\mathrm{~m}, 2 \mathrm{H}$, Ar), $7.84(\mathrm{~d}, 1 \mathrm{H}, \mathrm{Ar}, J=9.6 \mathrm{~Hz}), 7.96(\mathrm{~s}, 2 \mathrm{H}, \mathrm{Ar}), 8.45$ (exch br s, $1 \mathrm{H}$, $\mathrm{NH}), 8.51(\mathrm{~d}, 1 \mathrm{H}, \mathrm{Ar}, J=8.4 \mathrm{~Hz})$.

5-(Cyclopropanecarbonylamino)-1-(3-methylbenzoyl)-1H-indazole-3-carboxylic Acid Ethyl Ester (20f). Yield = 82\%; mp = 204-205 ${ }^{\circ} \mathrm{C}(\mathrm{EtOH}) .{ }^{1} \mathrm{H} \mathrm{NMR}\left(\mathrm{CDCl}_{3}\right) \delta 0.92\left(\mathrm{~m}, 2 \mathrm{H}, \mathrm{cC}_{3} \mathrm{H}_{11}\right), 1.17(\mathrm{~m}, 2 \mathrm{H}$, $\left.\mathrm{cC}_{3} \mathrm{H}_{11}\right), 1.50\left(\mathrm{t}, 3 \mathrm{H}, \mathrm{CH}_{2} \mathrm{CH}_{3}, J=7.2 \mathrm{~Hz}\right), 1.58\left(\mathrm{~m}, 1 \mathrm{H}, \mathrm{cC}_{3} \mathrm{H}_{11}\right)$, 2.47 (s, 3H, Ph- $\left.\mathrm{CH}_{3}\right), 4.53\left(\mathrm{q}, 2 \mathrm{H}, \mathrm{CH}_{2} \mathrm{CH}_{3}, \mathrm{~J}=7.2 \mathrm{~Hz}\right), 7.42-7.47$ (m, 2H, Ar), 7.60 (exch br s, 1H, NH), 7.,85 (d, 1H, Ar), 7.95 (s, 2H, $\mathrm{Ar}), 8.44(\mathrm{~s}, 1 \mathrm{H}, \mathrm{Ar}), 8.50$ (d, $1 \mathrm{H}, \mathrm{Ar}, J=9.2 \mathrm{~Hz}$ ).

5-(Cyclopentanecarbonylamino)-1-(3-methylbenzoyl)-1 Hindazole-3-carboxylic Acid Ethyl Ester (20g). Compound $20 \mathrm{~g}$ was obtained starting from 17 following the same procedure described for $\mathbf{1 4 c , d , g , h}$. After dilution with cold water, the mixture was neutralized with $0.5 \mathrm{~N} \mathrm{NaOH}$ and extracted with ethyl acetate $(3 \times 15 \mathrm{~mL})$. Evaporation of the solvent resulted in a residue, which was purified by crystallization from ethanol. Yield $=20 \% ; \mathrm{mp}=157-160{ }^{\circ} \mathrm{C}(\mathrm{EtOH})$. ${ }^{1} \mathrm{H} \mathrm{NMR}\left(\mathrm{CDCl}_{3}\right) \delta 1.50\left(\mathrm{t}, 3 \mathrm{H}, \mathrm{CH}_{2} \mathrm{CH}_{3}, J=7.2 \mathrm{~Hz}\right), 1.65-1.70(\mathrm{~m}$, $\left.2 \mathrm{H}, \mathrm{cC}_{5} \mathrm{H}_{9}\right), 1.85-1.88\left(\mathrm{~m}, 2 \mathrm{H}, \mathrm{cC}_{5} \mathrm{H}_{9}\right), 1.95-2.01\left(\mathrm{~m}, 4 \mathrm{H}, \mathrm{cC}_{5} \mathrm{H}_{9}\right)$, $2.47\left(\mathrm{~s}, 3 \mathrm{H}, \mathrm{Ph}-\mathrm{CH}_{3}\right), 2.73-2.80\left(\mathrm{~m}, 1 \mathrm{H}, \mathrm{cC}_{5} \mathrm{H}_{9}\right), 4.55(\mathrm{q}, 2 \mathrm{H}$, $\left.\mathrm{CH}_{2} \mathrm{CH}_{3}, \mathrm{~J}=7.2 \mathrm{~Hz}\right), 7.38-7.47(\mathrm{~m}, 3 \mathrm{H}, 1 \mathrm{H} \mathrm{NH}$ e $2 \mathrm{H} \mathrm{Ar}), 7.85(\mathrm{~d}$, $1 \mathrm{H}, \mathrm{Ar}, J=9.2 \mathrm{~Hz}$ ), 7.95 (s, 2H, Ar), 8.46 (s, 1H, Ar), 8.50 (d, 1H, Ar, $J=9.2 \mathrm{~Hz}$ ).

1-(3-Methylbenzoyl)-5-phenylamino- $1 \mathrm{H}$-indazole-3-carboxylic Acid Ethyl Ester (20h). A mixture of activated powdered 4A molecular sieves $(500 \mathrm{mg}), 0.30 \mathrm{mmol}$ of $17,5 \mathrm{~mL}$ of anhydrous $\mathrm{CH}_{2} \mathrm{Cl}_{2}, 0.60 \mathrm{mmol}$ of phenylboronic acid, $0.45 \mathrm{~mol}$ of $\mathrm{Cu}(\mathrm{Ac})_{2}$, and $0.60 \mathrm{~mol}$ of $\mathrm{Et}_{3} \mathrm{~N}$ was stirred for $24 \mathrm{~h}$ at room temperature. Molecular sieves were removed by suction filtration, and the organic layer was washed with $33 \%$ aqueous ammonia $(3 \times 5 \mathrm{~mL})$. Evaporation of the solvent resulted in the final compound, which was purified by flash chromatography using toluene/ethyl acetate 7:3 as eluent. Yield $=$ $71 \% ; \mathrm{mp}=123-125{ }^{\circ} \mathrm{C}(\mathrm{EtOH}) .{ }^{1} \mathrm{H}$ NMR $\left(\mathrm{CDCl}_{3}\right) \delta 1.45(\mathrm{t}, 3 \mathrm{H}$, $\mathrm{CH}_{2} \mathrm{CH}_{3}, J=7.2 \mathrm{~Hz}$ ), $2.46\left(\mathrm{~s}, 3 \mathrm{H}, \mathrm{Ph}-\mathrm{CH}_{3}\right), 4.50\left(\mathrm{q}, 2 \mathrm{H}, \mathrm{CH}_{2}, J=7.2\right.$ $\mathrm{Hz}), 7.03(\mathrm{t}, 1 \mathrm{H}, \mathrm{Ar}, J=7.2 \mathrm{~Hz}), 7.19(\mathrm{~d}, 2 \mathrm{H}, \mathrm{Ar}, J=8.0 \mathrm{~Hz}), 7.34(\mathrm{t}$, $2 \mathrm{H}, \mathrm{Ar}, J=8.0 \mathrm{~Hz}$ ), 7.39-7.44 (m, 3H, Ar), 7.94 (s, 3H, Ar), 8.44 (d, $1 \mathrm{H}, \mathrm{Ar}, J=9.2 \mathrm{~Hz}), 8.95$ (exch br s, $1 \mathrm{H}, \mathrm{NH})$.

7-Sulfamoyl-1H-indazole-3-carboxylic Acid (22). To 0.43 mmol of 21 (commercially available) cooled at $0{ }^{\circ} \mathrm{C}, 1 \mathrm{~mL}$ of chlorosulfonic acid was slowly added. The mixture was stirred at $80-$ $90{ }^{\circ} \mathrm{C}$ for $4-5 \mathrm{~h}$. After cooling, ice-cold water $(15 \mathrm{~mL}$ ) and $33 \%$ aqueous ammonia $(5 \mathrm{~mL})$ were added, resulting in a precipitate, which was recovered by suction. Yield $=10 \% ; \mathrm{mp}=257^{\circ} \mathrm{C} \operatorname{dec}(\mathrm{EtOH}) .{ }^{1} \mathrm{H}$ NMR (DMSO- $d_{6}$ ) $\delta 6.50$ (exch br s, $\left.1 \mathrm{H}, \mathrm{OH}\right), 7.24(\mathrm{t}, 1 \mathrm{H}, \mathrm{Ar}, J=8.4$ $\mathrm{Hz}$ ), $7.73(\mathrm{~d}, 1 \mathrm{H}, \mathrm{Ar}, J=6.8 \mathrm{~Hz}), 8.10$ (exch br s, $2 \mathrm{~h}, \mathrm{NH}_{2}$ ), 8.45 (d, $1 \mathrm{H}, \mathrm{Ar}, J=7.6 \mathrm{~Hz}$ )

7-Sulfamoyl-1 $\mathrm{H}$-indazole-3-carboxylic Acid Ethyl Ester (23). A mixture of $22(0.62 \mathrm{mmol})$ and a catalytic amount of conc $\mathrm{H}_{2} \mathrm{SO}_{4}$ in anhydrous ethanol $(7.5 \mathrm{~mL})$ was heated at $100{ }^{\circ} \mathrm{C}$ for $5 \mathrm{~h}$. After cooling, ice-cold water was added and the precipitate was recovered by suction and recrystallized from ethanol. Yield $=48 \% ; \mathrm{mp}=244^{\circ} \mathrm{C}$ dec (EtOH). ${ }^{1} \mathrm{H}$ NMR (DMSO- $\left.d_{6}\right) \delta 1.40\left(\mathrm{t}, 3 \mathrm{H}, \mathrm{CH}_{3}, J=7.2 \mathrm{~Hz}\right), 4.43$ (q, $2 \mathrm{H}, \mathrm{CH}_{2}, J=7.2 \mathrm{~Hz}$ ), $7.50(\mathrm{t}, 1 \mathrm{H}, \mathrm{Ar}, J=8.0 \mathrm{~Hz}$ ), 7.71 (exch br s, $2 \mathrm{H}, \mathrm{SO}_{2} \mathrm{NH}_{2}$ ), 7.90 (d, $\left.1 \mathrm{H}, \mathrm{Ar}, J=7.2 \mathrm{~Hz}\right), 8.34(\mathrm{~d}, 1 \mathrm{H}, \mathrm{Ar}, J=8.0$ $\mathrm{Hz}), 13.91($ exch br s, $1 \mathrm{H}, \mathrm{NH}) .{ }^{13} \mathrm{C}$ NMR (DMSO- $d_{6}$ ) $\delta 14.4(\mathrm{q})$, $60.9(\mathrm{t}), 122.7(\mathrm{~d}), 124.0(\mathrm{~s}), 125.7(2 d), 127.5$ (s), $135.2(\mathrm{~s}), 136.0$ (s), $162.0(\mathrm{~s})$.

General Procedures for 24a,b. Compounds 24a,b were obtained starting from 23 following the general procedure described for $\mathbf{5 a - c , e}$. After dilution with water and neutralization with $0.5 \mathrm{NaOH}$, the mixture was extracted with ethyl acetate $(3 \times 15 \mathrm{~mL})$. Evaporation of the solvent resulted in the final compounds, which were purified by flash chromatography using as eluents cyclohexane/ethyl acetate 2:1 for $24 a$ and $1: 2$ for $\mathbf{2 4 b}$.

1-Benzoyl-7-sulfamoyl-1H-indazole-3-carboxylic Acid Ethyl Ester (24a). Yield $=29 \%$; $\mathrm{mp}=139-140{ }^{\circ} \mathrm{C}(\mathrm{EtOH}) .{ }^{1} \mathrm{H}$ NMR (DMSO$\left.d_{6}\right) \delta 1.38-1.42\left(\mathrm{~m}, 3 \mathrm{H}, \mathrm{CH}_{3}\right), 4.45-4.60\left(\mathrm{~m}, 2 \mathrm{H}, \mathrm{CH}_{2}\right), 7.61-7.70$ (m, $2 \mathrm{H}, \mathrm{Ar}), 7.72-7.80(\mathrm{~m}, 1 \mathrm{H}, \mathrm{Ar}), 7.90-8.05(\mathrm{~m}, 1 \mathrm{H}, \mathrm{Ar}), 8.15(\mathrm{~d}$, $2 \mathrm{H}, \mathrm{Ar}, J=6.8 \mathrm{~Hz}), 8.45(\mathrm{~d}, 1 \mathrm{H}, \mathrm{Ar}, J=7.2 \mathrm{~Hz}), 8.52(\mathrm{~d}, 1 \mathrm{H}, \mathrm{Ar}, J=$ $7.2 \mathrm{~Hz})$.

1-(3-Methylbenzoyl)-7-sulfamoyl-1H-indazole-3-carboxylic Acid Ethyl Ester (24b). Yield $=17 \% ; \mathrm{mp}=176-178{ }^{\circ} \mathrm{C}(\mathrm{EtOH}) \cdot{ }^{1} \mathrm{H}$ NMR $\left(\mathrm{CDCl}_{3}\right) \delta 1.50-1.60\left(\mathrm{~m}, 3 \mathrm{H}, \mathrm{CH}_{3}\right), 2.51\left(\mathrm{~s}, 3 \mathrm{H}, \mathrm{Ph}-\mathrm{CH}_{3}\right)$, 4.58-4.65 (m, $2 \mathrm{H}, \mathrm{CH}_{2}$ ), 7.52 (s, $\left.2 \mathrm{H}, \mathrm{Ar}\right), 7.80-7.90$ (m, $\left.1 \mathrm{H}, \mathrm{Ar}\right)$, 8.17 (s, 1H, Ar), 8.22-8.27 (m, 2H, Ar), 8.51 (d, 1H, Ar).

General Procedures for 26a,b and 26f. Compounds 26a,b and 26f were obtained starting from $\mathbf{2 5 a}, \mathbf{b}^{32}$ following the same general procedure described for $\mathbf{5 a - c , e}$. For compound 26a, after dilution with water and neutralization with $\mathrm{NaOH}$, the crude precipitate was recovered by suction and crystallized by ethanol. The suspension of $26 \mathbf{b}$ and $26 \mathbf{f}$ was extracted with $\mathrm{CH}_{2} \mathrm{Cl}_{2}(3 \times 15 \mathrm{~mL})$, and evaporation of the solvent resulted in the final compounds, which were recrystallized from ethanol.

1-Benzoyl-5-bromo-1H-indazole-3-carboxylic Acid Methyl Ester (26a). Yield $=82 \% ; \mathrm{mp}=143-146{ }^{\circ} \mathrm{C}(\mathrm{EtOH}) .{ }^{1} \mathrm{H}$ NMR $\left(\mathrm{CDCl}_{3}\right) \delta$ 4.08 (s, $\left.3 \mathrm{H}, \mathrm{CH}_{3}\right), 7.55-7.60(\mathrm{~m}, 2 \mathrm{H}, \mathrm{Ar}), 7.65-7.71(\mathrm{~m}, 1 \mathrm{H}, \mathrm{Ar})$, $7.77(\mathrm{~d}, 1 \mathrm{H}, \mathrm{Ar}, J=7.2 \mathrm{~Hz}), 8.12-8.17(\mathrm{~m}, 2 \mathrm{H}, \mathrm{Ar}), 8.47(\mathrm{~d}, 1 \mathrm{H}, \mathrm{Ar}, J$ $=6.4 \mathrm{~Hz}), 8.49(\mathrm{~s}, 1 \mathrm{H}, \mathrm{Ar})$.

5-Bromo-1-(3-methylbenzoyl)-1H-indazole-3-carboxylic Acid Methyl Ester (26b). Yield $=58 \% ; \mathrm{mp}=121-123{ }^{\circ} \mathrm{C}(\mathrm{EtOH}) .{ }^{1} \mathrm{H}$ NMR $\left(\mathrm{CDCl}_{3}\right) \delta 2.48\left(\mathrm{~s}, 3 \mathrm{H}, \mathrm{Ph}-\mathrm{CH}_{3}\right), 4.07\left(\mathrm{~s}, 3 \mathrm{H}, \mathrm{OCH}_{3}\right), 7.43-$ $7.49(\mathrm{~m}, 2 \mathrm{H}, \mathrm{Ar}), 7.77$ (d, 1H, Ar, $J=9.2 \mathrm{~Hz}), 7.93(\mathrm{~d}, 2 \mathrm{H}, \mathrm{Ar}, J=7.2$ $\mathrm{Hz}), 8.46(\mathrm{~d}, 1 \mathrm{H}, \mathrm{Ar}, J=9.2 \mathrm{~Hz}), 8.48(\mathrm{~s}, 1 \mathrm{H}, \mathrm{Ar})$.

5-Bromo-1-(3-methylbenzoyl)-1H-indazole-3-carboxylic Acid Ethyl Ester (26f). Yield $=50 \% ; \mathrm{mp}=116-117{ }^{\circ} \mathrm{C}(\mathrm{EtOH}) .{ }^{1} \mathrm{H}$ NMR $\left(\mathrm{CDCl}_{3}\right) \delta 1.50\left(\mathrm{t}, 3 \mathrm{H}, \mathrm{CH}_{2} \mathrm{CH}_{3}, J=7.2 \mathrm{~Hz}\right), 2.48(\mathrm{~s}, 3 \mathrm{H}, \mathrm{Ph}-$ $\left.\mathrm{CH}_{3}\right), 4.55\left(\mathrm{q}, 2 \mathrm{H}, \mathrm{CH}_{2}, J=7.2 \mathrm{~Hz}\right), 7.43-7.49(\mathrm{~m}, 2 \mathrm{H}, \mathrm{Ar}), 7.76(\mathrm{~d}$, $1 \mathrm{H}, \mathrm{Ar}, J=8.0 \mathrm{~Hz}$ ), 7.95 (s, 2H, Ar), $8.45(\mathrm{~s}, 2 \mathrm{H}, \mathrm{Ar})$.

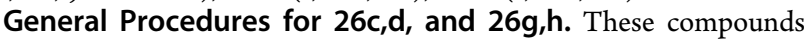
were obtained starting from compounds $25 \mathrm{a}^{32}$ or $25 \mathbf{b}^{32}$ following the general procedure described for $14 \mathrm{c}, \mathbf{d}, \mathbf{g}, \mathbf{h}$. For $26 \mathrm{~d}$ and $26 \mathrm{~h}$, the precipitate was recovered by suction and recrystallized from ethanol;

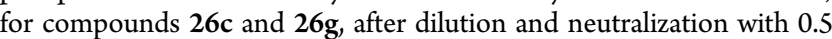
$\mathrm{N} \mathrm{NaOH}$, the suspension was extracted with $\mathrm{CH}_{2} \mathrm{Cl}_{2}(3 \times 15 \mathrm{~mL})$, and evaporation of the solvent resulted in the final compounds, which were purified by crystallization from ethanol.

5-Bromo-1-(3-methoxybenzoyl)-1H-indazole-3-carboxylic Acid Methyl Ester (26c). Yield $=26 \% ; \mathrm{mp}=105-108{ }^{\circ} \mathrm{C}(\mathrm{EtOH}) .{ }^{1} \mathrm{H}$ NMR $\left(\mathrm{CDCl}_{3}\right) \delta 3.91\left(\mathrm{~s}, 3 \mathrm{H}, \mathrm{OCH}_{3}\right), 4.07\left(\mathrm{~s}, 3 \mathrm{H}, \mathrm{COOCH}_{3}\right), 7.21$ 
(d, $1 \mathrm{H}, \mathrm{Ar}, J=6.4 \mathrm{~Hz}), 7.47(\mathrm{t}, 1 \mathrm{H}, \mathrm{Ar}, J=8.0 \mathrm{~Hz}), 7.68(\mathrm{~s}, 1 \mathrm{H}, \mathrm{Ar})$, $7.76(\mathrm{t}, 2 \mathrm{H}, \mathrm{Ar}, J=7.2 \mathrm{~Hz}), 8.45-8.53(\mathrm{~m}, 2 \mathrm{H}, \mathrm{Ar})$.

5-Bromo-1-(thiophene-3-carbonyl)-1H-indazole-3-carboxylic Acid Methyl Ester (26d). Yield $=36 \% ; \mathrm{mp}=136-138^{\circ} \mathrm{C}(\mathrm{EtOH}) .{ }^{1} \mathrm{H}$ NMR $\left(\mathrm{CDCl}_{3}\right) \delta 4.12\left(\mathrm{~s}, 3 \mathrm{H}, \mathrm{CH}_{3}\right), 7.43(\mathrm{t}, 1 \mathrm{H}, \mathrm{Ar}, J=4.8 \mathrm{~Hz}), 7.75$ $(\mathrm{d}, 1 \mathrm{H}, \mathrm{Ar}, J=8.8 \mathrm{~Hz}), 7.99(\mathrm{~d}, 1 \mathrm{H}, \mathrm{Ar}, J=5.2 \mathrm{~Hz}), 8.46(\mathrm{~s}, 1 \mathrm{H}, \mathrm{Ar})$, $8.50(\mathrm{~d}, 1 \mathrm{H}, \mathrm{Ar}, J=9.2 \mathrm{~Hz}), 8.94(\mathrm{~d}, 1 \mathrm{H}, \mathrm{Ar}, J=3.2 \mathrm{~Hz}$ ).

5-Bromo-1-(3-methoxybenzoyl)-1H-indazole-3-carboxylic Acid Ethyl Ester (26g). Yield = 54\%; mp $=115-117{ }^{\circ} \mathrm{C}(\mathrm{EtOH}) .{ }^{1} \mathrm{H}$ $\operatorname{NMR}\left(\mathrm{CDCl}_{3}\right) \delta 1.50\left(\mathrm{t}, 3 \mathrm{H}, \mathrm{CH}_{2} \mathrm{CH}_{3}, J=7.2 \mathrm{~Hz}\right), 3.91(\mathrm{~s}, 3 \mathrm{H}$, $\left.\mathrm{OCH}_{3}\right), 4.55\left(\mathrm{q}, 2 \mathrm{H}, \mathrm{CH}_{2} \mathrm{CH}_{3}, J=7.2 \mathrm{~Hz}\right), 7.21(\mathrm{~d}, 1 \mathrm{H}, \mathrm{Ar}, J=8.0$ $\mathrm{Hz}), 7.47(\mathrm{t}, 1 \mathrm{H}, \mathrm{Ar}, J=8.0 \mathrm{~Hz}), 7.72(\mathrm{~s}, 1 \mathrm{H}, \mathrm{Ar}), 7.77(\mathrm{~d}, 2 \mathrm{H}, \mathrm{Ar}, J=$ $8.0 \mathrm{~Hz}), 8.46(\mathrm{~d}, 2 \mathrm{H}, \mathrm{Ar}, J=8.4 \mathrm{~Hz})$.

5-Bromo-1-(thiophene-3-carbonyl)-1H-indazole-3-carboxylic Acid Ethyl Ester (26h). Yield $=35 \%$; $\mathrm{mp}=106-108{ }^{\circ} \mathrm{C}(\mathrm{EtOH}) .{ }^{1} \mathrm{H}$ $\operatorname{NMR}\left(\mathrm{CDCl}_{3}\right) \delta 1.53\left(\mathrm{t}, 3 \mathrm{H}, \mathrm{CH}_{2} \mathrm{CH}_{3}, J=7.2 \mathrm{~Hz}\right), 4.60(\mathrm{q}, 2 \mathrm{H}$, $\left.\mathrm{CH}_{2} \mathrm{CH}_{3}, J=7.2 \mathrm{~Hz}\right), 7.40-7.7 .45(\mathrm{~m}, 1 \mathrm{H}, \mathrm{Ar}), 7.75(\mathrm{~d}, 1 \mathrm{H}, \mathrm{Ar}, J=$ $9.2 \mathrm{~Hz}), 8.00(\mathrm{~d}, 1 \mathrm{H}, \mathrm{Ar}, J=5.2 \mathrm{~Hz}), 8.45(\mathrm{~s}, 1 \mathrm{H}, \mathrm{Ar}), 8.50(\mathrm{~d}, 1 \mathrm{H}, \mathrm{Ar}$, $J=9.2 \mathrm{~Hz}), 8.96(\mathrm{~s}, 1 \mathrm{H}, \mathrm{Ar})$.

5-Sulfamoyl-1H-indazole-3-carboxylic Acid (28f). A mixture of $27 \mathbf{f}^{36}(0.31 \mathrm{mmol})$ and $0.32 \mathrm{mmol}$ of $0.5 \mathrm{~N} \mathrm{NaOH}$ in $1 \mathrm{~mL}$ of water was stirred at $50{ }^{\circ} \mathrm{C}$ for $30 \mathrm{~min}$. After cooling, a solution of $\mathrm{NaNO}_{2}$ $(0.31 \mathrm{~mol})$ in water $(0.1 \mathrm{~mL})$ followed by a solution of conc $\mathrm{H}_{2} \mathrm{SO}_{4}$ $(0.60 \mathrm{mmol})$ in $0.8 \mathrm{~mL}$ of cold water were added, maintaining the mixture reaction under stirring at $0{ }^{\circ} \mathrm{C}$ for $1 \mathrm{~h}$. Finally, a cold solution of $\mathrm{SnCl}_{2}(0.74 \mathrm{mmol})$ in $0.5 \mathrm{~mL}$ of conc $\mathrm{HCl}$ was added, and the mixture was stirred for further $2 \mathrm{~h}$ at $0{ }^{\circ} \mathrm{C}$ and $16 \mathrm{~h}$ at room temperature. The precipitate was recovered by suction. Yield $=38 \%$; $\mathrm{mp}>300{ }^{\circ} \mathrm{C} \operatorname{dec}(\mathrm{EtOH}) .{ }^{1} \mathrm{H}$ NMR (DMSO- $\left.d_{6}\right) \delta 6.10$ (exch br s, $1 \mathrm{H}, \mathrm{OH}), 7.57$ (d, $1 \mathrm{H}, \mathrm{Ar}, J=7.2 \mathrm{~Hz}), 7.68(\mathrm{~d}, 1 \mathrm{H}, \mathrm{Ar}, J=8.4 \mathrm{~Hz})$, 8.18 (s, $1 \mathrm{H}, \mathrm{Ar}$ ), 8.40 (exch br s, $2 \mathrm{H}, \mathrm{NH}_{2}$ ), 13.95 (exch br s, $1 \mathrm{H}$, $\mathrm{NH})$.

General Procedures for 29e,f. Compounds 29e and 29f were obtained starting from $28 \mathrm{e}^{39}$ and $28 \mathrm{f}$ and following the same procedure described for compound 23.

5-Trifluoromethoxy-1H-indazole-3-carboxylic Acid Ethyl Ester (29e). Yield $=45 \%$; mp $=179-181{ }^{\circ} \mathrm{C}(\mathrm{EtOH}) .{ }^{1} \mathrm{H}$ NMR $\left(\mathrm{CDCl}_{3}\right)$ $\delta 1.53\left(\mathrm{t}, 3 \mathrm{H}, \mathrm{CH}_{3}, J=7.2 \mathrm{~Hz}\right), 4.57\left(\mathrm{q}, 2 \mathrm{H}, \mathrm{CH}_{2}, J=7.2 \mathrm{~Hz}\right), 7.39(\mathrm{~d}$, $1 \mathrm{H}, \mathrm{Ar}, J=8.8 \mathrm{~Hz}), 7.70(\mathrm{~d}, 1 \mathrm{H}, \mathrm{Ar}, J=8.8 \mathrm{~Hz}), 8.11(\mathrm{~s}, 1 \mathrm{H}, \mathrm{Ar})$, 12.87 (exch br s, $1 \mathrm{H}, \mathrm{NH}$ ).

5-Sulfamoyl-1H-indazole-3-carboxylic Acid Ethyl Ester (29f). Yield $=95 \% ; \mathrm{mp}=290{ }^{\circ} \mathrm{C}(\mathrm{EtOH}) .{ }^{1} \mathrm{H}$ NMR $\left(\right.$ DMSO- $\left.d_{6}\right) \delta 1.15-$ $1.25\left(\mathrm{~m}, 3 \mathrm{H}, \mathrm{CH}_{3}\right), 4.24\left(\mathrm{q}, 2 \mathrm{H}, \mathrm{CH}_{2}, J=7.2 \mathrm{~Hz}\right) 7.62(\mathrm{~d}, 1 \mathrm{H}, \mathrm{Ar}, J=$ $7.2 \mathrm{~Hz}$ ), 7.72 (d, $1 \mathrm{H}, \mathrm{Ar}, J=8.8 \mathrm{~Hz}$ ), 8.08 (s, $1 \mathrm{H}, \mathrm{Ar}$ ), 9.05 (exch br s, $2 \mathrm{H}, \mathrm{NH}_{2}$ ), 14.10 (exch br s, $1 \mathrm{H}, \mathrm{NH}$ ).

5-Hydroxy-1H-indazole-3-carboxylic Acid Ethyl Ester (30). To a cooled $\left(-78{ }^{\circ} \mathrm{C}\right)$ solution of $29 \mathrm{~d}^{38}(1.08 \mathrm{mmol})$ in $1 \mathrm{~mL}$ of anhydrous $\mathrm{CH}_{2} \mathrm{Cl}_{2}, 4.15 \mathrm{~mL}$ of $\mathrm{BBr}_{3}\left(1 \mathrm{M}\right.$ in $\left.\mathrm{CH}_{2} \mathrm{Cl}_{2}\right)$ were added. The reaction was carried out under nitrogen, and after $10 \mathrm{~min}$ the mixture was allowed to warm to room temperature and stirred for $3 \mathrm{~h}$. After dilution with water, the mixture was extracted with ethyl acetate $(3 \times 15 \mathrm{~mL})$, and the organic layers were evaporated to obtain compound 30, which was purified by flash column chromatography using cyclohexane/ethyl acetate $1: 1$ as eluent. Yield $=14 \%$; oil. ${ }^{1} \mathrm{H}$ $\operatorname{NMR}\left(\mathrm{CDCl}_{3}\right) \delta 1.51\left(\mathrm{t}, 3 \mathrm{H}, \mathrm{CH}_{3}, J=7.2 \mathrm{~Hz}\right), 4.53\left(\mathrm{q}, 2 \mathrm{H}, \mathrm{CH}_{2}, J=\right.$ $7.2 \mathrm{~Hz}), 7.11(\mathrm{~d}, 1 \mathrm{H}, \mathrm{Ar}, J=8.8 \mathrm{~Hz}), 7.47(\mathrm{~d}, 1 \mathrm{H}, \mathrm{Ar}, J=9.2 \mathrm{~Hz}), 7.61$ (s, 1H, Ar).

General Procedures for $31 \mathrm{a}-\mathrm{g}$ and $31 \mathrm{i}$. Compounds $31 \mathrm{a}-\mathrm{g}$ and $31 \mathrm{i}$ were obtained following the general procedure described for $5 a-c$ and 5e starting from compounds $29 a-f\left(29 a-c^{37}\right.$ and $\left.29 d^{38}\right)$. Compounds $31 \mathrm{a}-\mathrm{g}$ were recrystallized from ethanol, while compound 31i was purified by flash chromatography using toluene/ethyl acetate 99:1 as eluent.

5-Methyl-1-(3-methylbenzoyl)-1H-indazole-3-carboxylic Acid Ethyl Ester (31a). Yield $=13 \% ; \mathrm{mp}=88{ }^{\circ} \mathrm{C}(\mathrm{EtOH}) .{ }^{1} \mathrm{H}$ NMR $\left(\mathrm{CDCl}_{3}\right) \delta 1.50\left(\mathrm{t}, 3 \mathrm{H}, \mathrm{CH}_{2} \mathrm{CH}_{3}, J=7.2 \mathrm{~Hz}\right), 2.47\left(\mathrm{~s}, 3 \mathrm{H}, \mathrm{Ph}-\mathrm{CH}_{3}\right)$, $2.57\left(\mathrm{~s}, 3 \mathrm{H}, 5-\mathrm{CH}_{3}\right), 4.54\left(\mathrm{q}, 2 \mathrm{H}, \mathrm{CH}_{2}, J=7.2 \mathrm{~Hz}\right), 7.43-7.45(\mathrm{~m}, 2 \mathrm{H}$, $\mathrm{Ar}), 7.50(\mathrm{~d}, 1 \mathrm{H}, \mathrm{Ar}, J=8.4 \mathrm{~Hz}), 7.93-7.97(\mathrm{~m}, 2 \mathrm{H}, \mathrm{Ar}), 8.07(\mathrm{~s}, 1 \mathrm{H}$, Ar), $8.45(\mathrm{~d}, 1 \mathrm{H}, \mathrm{Ar}, J=8.4 \mathrm{~Hz})$.
5-Chloro-1-(3-methylbenzoyl)-1H-indazole-3-carboxylic Acid Ethyl Ester (31b). Yield $=27 \% ; \mathrm{mp}=108{ }^{\circ} \mathrm{C}(\mathrm{EtOH}) .{ }^{1} \mathrm{H}$ NMR $\left(\mathrm{CDCl}_{3}\right) \delta 1.50\left(\mathrm{t}, 3 \mathrm{H}, \mathrm{CH}_{2} \mathrm{CH}_{3}, J=7.2 \mathrm{~Hz}\right), 2.48\left(\mathrm{~s}, 3 \mathrm{H}, \mathrm{Ph}-\mathrm{CH}_{3}\right)$, $4.55\left(\mathrm{q}, 2 \mathrm{H}, \mathrm{CH}_{2}, J=7.2 \mathrm{~Hz}\right), 7.43-7.49(\mathrm{~m}, 2 \mathrm{H}, \mathrm{Ar}), 7.63(\mathrm{~d}, 1 \mathrm{H}, \mathrm{Ar}$, $J=8.8 \mathrm{~Hz}), 7.95(\mathrm{~s}, 2 \mathrm{H}, \mathrm{Ar}), 8.28(\mathrm{~s}, 1 \mathrm{H}, \mathrm{Ar}), 8.52(\mathrm{~d}, 1 \mathrm{H}, \mathrm{Ar}, J=9.2$ $\mathrm{Hz})$.

5-Fluoro-1-(3-methylbenzoyl)-1H-indazole-3-carboxylic Acid Ethyl Ester (31c). Yield $=23 \% ; \mathrm{mp}=105{ }^{\circ} \mathrm{C}(\mathrm{EtOH}) .{ }^{1} \mathrm{H}$ NMR $\left(\mathrm{CDCl}_{3}\right) \delta 1.50\left(\mathrm{t}, 3 \mathrm{H}, \mathrm{CH}_{2} \mathrm{CH}_{3}, J=7.2 \mathrm{~Hz}\right), 2.48\left(\mathrm{~s}, 3 \mathrm{H}, \mathrm{Ph}-\mathrm{CH}_{3}\right)$, $4.55\left(\mathrm{q}, 2 \mathrm{H}, \mathrm{CH}_{2}, J=7.2 \mathrm{~Hz}\right), 7.40-7.49(\mathrm{~m}, 3 \mathrm{H}, \mathrm{Ar}), 7.92-7.96(\mathrm{~m}$, $3 \mathrm{H}, \mathrm{Ar}), 8.56(\mathrm{~d}, 1 \mathrm{H}, \mathrm{Ar}, J=5.2 \mathrm{~Hz})$.

1-Benzoyl-5-methoxy-1H-indazole-3-carboxylic Acid Ethyl Ester (31d). Yield = 21\%; $\mathrm{mp}=111-112{ }^{\circ} \mathrm{C}(\mathrm{EtOH}) .{ }^{1} \mathrm{H}$ NMR (DMSO$\left.d_{6}\right) \delta 1.38\left(\mathrm{t}, 3 \mathrm{H}, \mathrm{CH}_{2} \mathrm{CH}_{3}, J=7.2 \mathrm{~Hz}\right), 3.90\left(\mathrm{~s}, 3 \mathrm{H}, \mathrm{OCH}_{3}\right), 4.45(\mathrm{q}$, $\left.2 \mathrm{H}, \mathrm{CH}_{2}, J=7.2 \mathrm{~Hz}\right), 7.39(\mathrm{~d}, 1 \mathrm{H}, \mathrm{Ar}, J=9.2 \mathrm{~Hz}), 7.58-7.72(\mathrm{~m}, 4 \mathrm{H}$, Ar), $7.78-7.82(\mathrm{~m}, 2 \mathrm{H}, \mathrm{Ar}), 8.37$ (d, $1 \mathrm{H}, \mathrm{Ar}, J=8.8 \mathrm{~Hz}$ ).

5-Methoxy-1-(3-methylbenzoyl)-1H-indazole-3-carboxylic Acid Ethyl Ester (31e). Yield $=20 \% ; \mathrm{mp}=89-90{ }^{\circ} \mathrm{C}(\mathrm{EtOH}) .{ }^{1} \mathrm{H}$ NMR $\left(\right.$ DMSO- $\left.d_{6}\right) \delta 1.37\left(\mathrm{t}, 3 \mathrm{H}, \mathrm{CH}_{2} \mathrm{CH}_{3}, J=7.2 \mathrm{~Hz}\right), 2.42(\mathrm{~s}, 3 \mathrm{H}, \mathrm{Ph}-$ $\left.\mathrm{CH}_{3}\right), 3.90\left(\mathrm{~s}, 3 \mathrm{H}, \mathrm{OCH}_{3}\right), 4.44\left(\mathrm{q}, 2 \mathrm{H}, \mathrm{CH}_{2}, J=7.2 \mathrm{~Hz}\right), 7.39(\mathrm{~d}, 1 \mathrm{H}$, $\mathrm{Ar}, J=9.2 \mathrm{~Hz}), 7.48-7.53(\mathrm{~m}, 2 \mathrm{H}, \mathrm{Ar}), 7.58(\mathrm{~s}, 1 \mathrm{H}, \mathrm{Ar}), 7.78-7.82$ $(\mathrm{m}, 2 \mathrm{H}, \mathrm{Ar}), 8.35(\mathrm{~d}, 1 \mathrm{H}, \mathrm{Ar}, J=8.8 \mathrm{~Hz})$.

1-Benzoyl-5-trifluoromethoxy-1H-indazole-3-carboxylic Acid Ethyl Ester (31f). Yield $=22 \%$; mp $=91-92{ }^{\circ} \mathrm{C}(\mathrm{EtOH}) .{ }^{1} \mathrm{H}$ NMR $\left(\mathrm{CDCl}_{3}\right) \delta 1.51\left(\mathrm{t}, 3 \mathrm{H}, \mathrm{CH}_{2} \mathrm{CH}_{3}, J=7.2 \mathrm{~Hz}\right), 4.56\left(\mathrm{q}, 2 \mathrm{H}, \mathrm{CH}_{3} \mathrm{CH}_{2}, J\right.$ $=7.2 \mathrm{~Hz}), 7.54-7.60(\mathrm{~m}, 3 \mathrm{H}, \mathrm{Ar}), 7.68(\mathrm{t}, 1 \mathrm{H}, \mathrm{Ar}, J=7.6 \mathrm{~Hz}), 8.16-$ $8.19(\mathrm{~m}, 3 \mathrm{H}, \mathrm{Ar}), 8.62(\mathrm{~d}, 1 \mathrm{H}, \mathrm{Ar}, J=9.2 \mathrm{~Hz})$.

1-(3-Methylbenzoyl)-5-trifluoromethoxy-1H-indazole-3-carboxylic Acid Ethyl Ester (31g). Yield $=28 \%$; mp $=112-113{ }^{\circ} \mathrm{C}(\mathrm{EtOH})$. ${ }^{1} \mathrm{H}$ NMR $\left(\mathrm{CDCl}_{3}\right) \delta 1.51\left(\mathrm{t}, 3 \mathrm{H}, \mathrm{CH}_{2} \mathrm{CH}_{3}, J=7.2 \mathrm{~Hz}\right), 2.48(\mathrm{~s}, 3 \mathrm{H}$, $\left.\mathrm{Ph}-\mathrm{CH}_{3}\right), 4.56\left(\mathrm{q}, 2 \mathrm{H}, \mathrm{CH}_{2}, J=7.2 \mathrm{~Hz}\right), 7.43-7.50(\mathrm{~m}, 2 \mathrm{H}, \mathrm{Ar}), 7.54$ $(\mathrm{d}, 1 \mathrm{H}, \mathrm{Ar}, J=8.8 \mathrm{~Hz}), 7.96(\mathrm{~s}, 2 \mathrm{H}, \mathrm{Ar}), 8.16(\mathrm{~s}, 1 \mathrm{H}, \mathrm{Ar}), 8.61(\mathrm{~d}, 1 \mathrm{H}$, Ar, $J=9.2 \mathrm{~Hz})$.

1-(3-Methylbenzoyl)-5-sulfamoyl-1H-indazole-3-carboxylic Acid Ethyl Ester (31i). Yield $=28 \% ; \mathrm{mp}=52-54{ }^{\circ} \mathrm{C}(\mathrm{EtOH}) .{ }^{1} \mathrm{H}$ NMR $\left(\mathrm{CDCl}_{3}\right) \delta 1.43\left(\mathrm{t}, 3 \mathrm{H}, \mathrm{CH}_{2} \mathrm{CH}_{3}, J=7.2 \mathrm{~Hz}\right), 2.46\left(\mathrm{~s}, 3 \mathrm{H}, \mathrm{Ph}-\mathrm{CH}_{3}\right)$, $4.49\left(\mathrm{q}, 2 \mathrm{H}, \mathrm{CH}_{2}, J=6.4 \mathrm{~Hz}\right), 7.41-7.47(\mathrm{~m}, 2 \mathrm{H}, \mathrm{Ar}), 7.83(\mathrm{~d}, 1 \mathrm{H}, \mathrm{Ar}$, $J=7.6 \mathrm{~Hz}), 7.91(\mathrm{~s}, 2 \mathrm{H}, \mathrm{Ar}), 8.46(\mathrm{~s}, 1 \mathrm{H}, \mathrm{Ar}), 8.53$ (d, 1H, Ar, $J=8.0$ $\mathrm{Hz})$.

5-Hydroxy-1-(3-methylbenzoyl)-1H-indazole-3-carboxylic Acid Ethyl Ester (31h). To a cooled and stirred solution of $m$-toluic acid $(0.52 \mathrm{mmol})$ and $\mathrm{Et}_{3} \mathrm{~N}(0.05 \mathrm{~mL})$ in anhydrous DMF $(1-2 \mathrm{~mL})$, diethylcyanophosphonate (DCF) $(2.08 \mathrm{mmol})$ and $0.52 \mathrm{mmol}$ of 30 were added. The mixture was stirred at room temperature for $16 \mathrm{~h}$. After dilution with ice-cold water $(10 \mathrm{~mL})$, the suspension was extracted with $\mathrm{CH}_{2} \mathrm{Cl}_{2}(3 \times 15 \mathrm{~mL})$ and evaporation of the solvent resulted in the final compound, which was purified by column chromatography using toluene/ethyl acetate $8: 2$ as eluent. Yield = $51 \% ; \mathrm{mp}=145-146{ }^{\circ} \mathrm{C}(\mathrm{EtOH}) .{ }^{1} \mathrm{H} \mathrm{NMR}\left(\mathrm{CDCl}_{3}\right) \delta 1.49(\mathrm{t}, 3 \mathrm{H}$, $\left.\mathrm{CH}_{2} \mathrm{CH}_{3}, \mathrm{~J}=7.2 \mathrm{~Hz}\right), 2.47\left(\mathrm{~s}, 3 \mathrm{H}, \mathrm{Ph}-\mathrm{CH}_{3}\right), 4.53\left(\mathrm{q}, 2 \mathrm{H}, \mathrm{CH}_{3} \mathrm{CH}_{2}, \mathrm{~J}=\right.$ $7.2 \mathrm{~Hz}$ ), $7.23(\mathrm{~d}, 1 \mathrm{H}, \mathrm{Ar}, J=8.8 \mathrm{~Hz}), 7.42-7.45(\mathrm{~m}, 2 \mathrm{H}, \mathrm{Ar}), 7.65(\mathrm{~s}$, $1 \mathrm{H}, \mathrm{Ar}), 7.96$ (s, 2H, Ar), 8.46 (d, $1 \mathrm{H}, \mathrm{Ar}, J=9.2 \mathrm{~Hz}$ ).

1-(3-Methylbenzoyl)-5-nitro-1 $\mathrm{H}$-indazole-3-carbonitrile (33). Compound 33 was obtained starting from compound $32^{40}$ and following the general procedure described for $5 \mathbf{a}-\mathbf{c}$ and $\mathbf{5 e}$. The final compound was purified by flash chromatography using toluene/ethyl acetate 8:2 as eluent. Yield $=32 \% ; \mathrm{mp}=140-143{ }^{\circ} \mathrm{C}(\mathrm{EtOH}) .{ }^{1} \mathrm{H}$ $\operatorname{NMR}\left(\mathrm{CDCl}_{3}\right) \delta 2.51\left(\mathrm{~s}, 3 \mathrm{H}, \mathrm{CH}_{3}\right), 7.50(\mathrm{t}, 1 \mathrm{H}, \mathrm{Ar}, J=8.0 \mathrm{~Hz}), 7.55$ $(\mathrm{d}, 1 \mathrm{H}, \mathrm{Ar}, J=7.6 \mathrm{~Hz}), 7.90(\mathrm{~s}, 2 \mathrm{H}, \mathrm{Ar}), 8.62(\mathrm{dd}, 1 \mathrm{H}, \mathrm{Ar}, J=2.0 \mathrm{~Hz}, J$ $=9.6 \mathrm{~Hz}), 8.77(\mathrm{~d}, 1 \mathrm{H}, \mathrm{Ar}, J=9.6 \mathrm{~Hz}), 8.89(\mathrm{~s}, 1 \mathrm{H}, \mathrm{Ar})$.

HNE Inhibition Assay. Compounds were dissolved in $100 \%$ DMSO at $5 \mathrm{mM}$ stock concentrations. The final concentration of DMSO in the reactions was $1 \%$, and this level of DMSO had no effect on enzyme activity. The HNE inhibition assay was performed in black, flat-bottom 96-well microtiter plates. Briefly, a buffer solution containing $200 \mathrm{mM}$ Tris- $\mathrm{HCl}, \mathrm{pH} 7.5,0.01 \%$ bovine serum albumin, and $0.05 \%$ Tween- 20 and $20 \mathrm{mU} / \mathrm{mL}$ of HNE (Calbiochem) was added to wells containing different concentrations of each compound. Reactions were initiated by addition of $25 \mu \mathrm{M}$ elastase substrate $(\mathrm{N}$ methylsuccinyl-Ala-Ala-Pro-Val-7-amino-4-methylcoumarin, Calbiochem) in a final reaction volume of $100 \mu \mathrm{L} /$ well. Kinetic measure- 
ments were obtained every $30 \mathrm{~s}$ for $10 \mathrm{~min}$ at $25{ }^{\circ} \mathrm{C}$ using a Fluoroskan Ascent FL fluorescence microplate reader (Thermo Electron, MA) with excitation and emission wavelengths at 355 and $460 \mathrm{~nm}$, respectively. For all compounds tested, the concentration of inhibitor that caused $50 \%$ inhibition of the enzymatic reaction $\left(\mathrm{IC}_{50}\right)$ was calculated by plotting $\%$ inhibition versus logarithm of inhibitor concentration (at least six points). The data are presented as the mean values of at least three independent experiments with relative standard deviations of $<15 \%$.

Analysis of Inhibitor Specificity. Selected compounds were evaluated for their ability to inhibit a range of proteases in $100 \mu \mathrm{L}$ reaction volumes at $25{ }^{\circ} \mathrm{C}$, as described previously. ${ }^{25}$ Briefly, analysis of chymotrypsin inhibition was performed in reaction mixtures containing $0.05 \mathrm{M}$ Tris- $\mathrm{HCl}, \mathrm{pH}$ 8.0, $30 \mathrm{nM}$ human pancreas chymotrypsin, test compounds, and $100 \mu \mathrm{M}$ substrate (Suc-Ala-AlaPro-Phe-7-amino-4-methylcoumarin). Thrombin inhibition was evaluated in reaction mixtures containing $0.25 \mathrm{M}$ sodium phosphate, $\mathrm{pH}$ 7.0, 0.2 M NaCl, 0.1\% PEG 8000, $1.7 \mathrm{U} / \mathrm{mL}$ human plasma thrombin, test compounds, and $20 \mu \mathrm{M}$ substrate (benzoyl-Phe-Val-Arg-7-amino4-methylcoumarin). Analysis of kallikrein inhibition was performed in reaction mixtures containing $0.05 \mathrm{M}$ Tris- $\mathrm{HCl}, \mathrm{pH} 8.0,0.1 \mathrm{M} \mathrm{NaCl}$, 0.05\% Tween-20, $2 \mathrm{nM}$ human plasma kallikrein, test compounds, and $50 \mu \mathrm{M}$ substrate (benzyloxycarbonyl-Phe-Arg-7-amino-4-methylcoumarin). Analysis of urokinase inhibition assay was performed in reaction mixtures containing $0.1 \mathrm{M}$ Tris- $\mathrm{HCl}, \mathrm{pH} 8.0,30 \mathrm{U} / \mathrm{mL}$ human urine urokinase, test compounds, and $30 \mu \mathrm{M}$ substrate (benzyloxycarbonyl-Gly-Gly-Arg-7-amino-4-methylcoumarin). Analysis of cathepsin $\mathrm{D}$ inhibition was performed in reaction mixtures containing $0.1 \mathrm{M}$ sodium acetate, $\mathrm{pH} 5.0,0.1 \mathrm{U} / \mathrm{mL}$ human spleen cathepsin $\mathrm{D}$, test compounds, and $5 \mu \mathrm{M}$ substrate (MOCAc-Gly-LysPro-Ile-Leu-Phe-Phe-Arg-Leu-Lys(Dnp)-D-Arg- $\mathrm{NH}_{2}$ ). Cathepsin D assays were monitored with a Fluoroskan Ascent FL microtiter plate reader at excitation and emission wavelengths of 340 and $390 \mathrm{~nm}$, respectively. For all serine proteases (chymotrypsin, thrombin, kallikrein, and urokinase), activity was monitored at excitation and emission wavelengths of 355 and $460 \mathrm{~nm}$, respectively. For all compounds tested, the concentration of inhibitor that caused 50\% inhibition of the enzymatic reaction $\left(\mathrm{IC}_{50}\right.$ ) was calculated by plotting $\%$ inhibition vs logarithm of inhibitor concentration (at least six points), and the data are the mean values of at least three experiments with relative standard deviations of $<15 \%$.

Analysis of Compound Stability. Spontaneous hydrolysis of selected indazole derivatives was evaluated at $25{ }^{\circ} \mathrm{C}$ in $0.05 \mathrm{M}$ phosphate buffer, $\mathrm{pH}$ 7.3. Kinetics of hydrolysis were monitored by measuring changes in absorbance spectra over time using a SpectraMax Plus microplate spectrophotometer (Molecular Devices, Sunnyvale, CA). Absorbance $\left(A_{\mathrm{t}}\right)$ at the characteristic absorption maxima of each $N$-benzoylpyrazole was measured at the indicated times until no further absorbance decreases occurred $\left(A_{\infty}\right) \cdot{ }^{43}$ Using these measurements, we created semilogarithmic plots of $\log \left(A_{t}-\right.$ $\left.A_{\infty}\right)$ vs time and $k^{\prime}$ values were determined from the slopes of these plots. Half-conversion times were calculated using $t_{1 / 2}=0.693 / k^{\prime}$, as described previously. ${ }^{25}$

Molecular Modeling. For molecular modeling, we used HyperChem 7.0 (Hypercube Inc., Waterloo, ON, Canada) and Molegro Virtual Docker (MVD), version 4.2.0 (CLC bio, Denmark) software. Molecular structures of compounds $5 \mathrm{~b}, 5 \mathrm{~d}, \mathbf{8}, \mathbf{1 4 f}, \mathbf{2 6 \mathrm { b }}$, and $31 \mathrm{~h}$ were generated in HyperChem and optimized with the use of the semiempirical PM3 method. These structures were then saved in the Tripos Mol2 format and imported into the MVD program for docking into the HNE binding site.

The structure of HNE complexed with a peptide chloromethyl ketone inhibitor ${ }^{41}$ was downloaded from the Protein Data Bank (1HNE entry of the database). The search area for docking poses was defined as a sphere with $10 \AA$ Aradius centered at the nitrogen atom in the five-membered ring of the peptide chloromethyl ketone inhibitor. After removal of this peptide and cocrystallized water molecules from the program workspace, we set side chain flexibility for 42 residues closest to the center of the search area (His40, Phe41, Cys42, Gly43, Ala55, Ala56, His57, Cys58, Val59, Ala60, Tyr94, Pro98, Asn99A,
Leu99B, Asp102, Trp141, Gly142, Leu143, Leu167, Arg177, Val190, Cys191, Phe192, Gly193, Asp194, Ser195, Gly196, Ser197, Ala213, Ser214, Phe215, Val216, Arg217A, Gly218, Gly219, Cys220, Ser222, Leu223, Tyr224, Asp226, Ala227, Phe228). To simulate the receptor flexibility, the standard technique built in the Molegro program was employed, i.e., docking a ligand with softened potentials was followed by optimization of flexible side chains with respect to the found pose. Further simultaneous minimization of these side chains and the pose using nonsoftened potentials was applied (Molegro Virtual Docker. User Manual, 2010). Values of 0.9 and 0.7 , respectively, were assigned to the "Tolerance" and "Strength" parameters of the MVD "Side chain Flexibility" wizard. Fifteen docking runs were performed for each compound, with full flexibility of a ligand around all rotatable bonds and side chain flexibility of the selected residues of the enzyme (see above).

The docking poses corresponding to the lowest-energy binding mode of each inhibitor were evaluated for the ability to form a Michaelis complex between the hydroxyl group of Ser195 and the carbonyl group in the amido moiety of an inhibitor. For this purpose, values of $d_{1}$ [distance $\mathrm{O}($ Ser195) $\cdots \mathrm{C}$ between the Ser195 hydroxyl oxygen atom and the carbonyl carbon atom of the amido moiety] and $\alpha$ [angle $\mathrm{O}($ Ser195 $) \cdots \mathrm{C}=\mathrm{O}$, where $\mathrm{C}=\mathrm{O}$ is the carbonyl group of an inhibitor amido moiety] were determined for each docked compound $^{44}$ (Supporting Information Figure S1). In addition, we estimated the possibility of proton transfer from Ser195 to Asp102 through His 57 (the key catalytic triad of serine proteases ${ }^{41,45,46,47}$ ) by calculating distances $d_{2}$ between the $\mathrm{NH}$ hydrogen in His57 and carboxyl oxygen atoms in Asp102. The distance between the hydroxyl proton in Ser195, and the pyridine-type nitrogen in His57 is also important for proton transfer. However, because of easy rotation of the hydroxyl about the $\mathrm{C}-\mathrm{O}$ bond in Ser195, we measured distance $d_{3}$ between the oxygen in Ser195 and the basic nitrogen atom in His57. The effective length $L$ of the channel for proton transfer was calculated as $L=d_{3}+\min \left(d_{2}\right)$.

\section{ASSOCIATED CONTENT}

\section{S Supporting Information}

Chemical and physical characteristics and spectral data for all the remaining new intermediates $5 \mathbf{c}, 5 \mathbf{e}, \mathbf{1 4} \mathbf{f}-\mathbf{h}, \mathbf{2 0 c}, \mathbf{2 0 d}-\mathbf{f}$, $\mathbf{2 6 f}-\mathbf{h}, \mathbf{3 1} \mathbf{c}-\mathbf{g}$, and 31i, elemental analyses for all final new compounds, geometric parameters important for formation of a Michaelis complex in the HNE active site, Docking pose of inactive compound 8. This material is available free of charge via the Internet at http://pubs.acs.org.

\section{AUTHOR INFORMATION}

\section{Corresponding Author}

*Phone: +39-055-4573682. Fax: +39 55 4573671. E-mail: mariapaola.giovannoni@unifi.it.

\section{Notes}

The authors declare no competing financial interest.

\section{ACKNOWLEDGMENTS}

This work was supported in part by an Institutional Development Award (IDeA) from the National Institute of General Medical Sciences of the National Institutes of Health under grant number GM103500, an equipment grant from the M. J. Murdock Charitable Trust, and the Montana State University Agricultural Experimental Station.

\section{ABBREVIATION USED}

HNE, human neutrophil elastase; ARDS, acute respiratory distress syndrome; CF, cystic fibrosis; His, histidine; Asp, aspartic acid; Ser, serine; Cys, cysteine; SD, standard deviation; NA, not active 


\section{REFERENCES}

(1) Travis, J.; Dubin, A.; Potempa, J.; Watorek, W.; Kurdowska, A. Neutrophil proteinases. Ann. N.Y. Acad. Sci. 1991, 624, 81-86.

(2) Zhou, X.; Dai, Q.; Huang, X. Neutrophils in acute lung injury. Front. Biosci. 2012, 17, 2278-2283.

(3) Sinha, S.; Watorek, W.; Karr, S.; Giles, J.; Bode, W.; Travis, J. Primary structure of human neutrophil elastase. Proc. Natl. Acad. Sci. U. S. A. 1987, 84, 2228-2232.

(4) Stockley, R. A. Neutrophils and protease/antiprotease imbalance. Am. J. Respir. Crit. Care Med. 1999, 160, 49-52.

(5) Heutinck, K. M.; ten Berge, I. J.; Hack, C. E.; Hamann, J.; Rowshani, A. T. Serine proteases of the human immune system in health and disease. Mol. Immunol. 2010, 47, 1943-1955.

(6) Mannino, D. M. Epidemiology and global impact of chronic obstructive pulmonary disease. Semin. Resp. Crit. Care Med. 2005, 26, 204-210.

(7) Hogg, J. C.; Chu, F.; Utokaparch, S.; Woods, R.; Elliott, W. M.; Buzatu, L.; CherniacK, R. M.; Rogers, R. M.; Sciurba, F. C.; Coxson, H. O.; Parè, P. D. The nature of small-airway obstruction in chronic obstructive pulmonary disease. N. Engl. J. Med. 2004, 350, 2645-2653.

(8) O'Donnell, R.; Peebles, A.; Ward, C.; Daraker, J. A.; Angco, A.; Broberg, P.; Pierrou, S.; Lund, J.; Holgate, S. T.; Davies, D. E.; Delany, D. J.; Wilson, S. J.; Djukanovic, R. Relationship between peripheral airway dysfunction, airway obstruction and neutrophilic inflammation in COPD. Thorax 2004, 59, 837-842.

(9) Straubaugh, S. D.; Davis, P. B. Cystic fibrosis: a review of epidemiology and pathology. Clin. Chest Med. 2007, 28, 279-288.

(10) Dollery, C. M.; Owen, C. A.; Sukhova, G. K.; Krettek, A.; Shapiro, S. D.; Libby, P. Neutrophil elastase in human atherosclerotic plaques: production by macrophages. Circulation 2003, 107, 28292836.

(11) Henriksen, P. A.; Sallenave, J.-M. Human neutrophil elastase: mediator and therapeutic target in atherosclerosis. Int. J. Biochem. Cell B 2008, 40, 1095-1100.

(12) Kawabata, K.; Moore, A. R.; Willoughby, D. A. Impaired activity of protease inhibitors towards neutrophil elastase bound to human articular cartilage. Ann. Rheum. Dis. 1996, 55, 248-252.

(13) Wiedow, O.; Wiese, F.; Streit, V.; Kalm, C.; Cristopher, E. Lesional elastase activity in psoriasis, contact dermatitis, and atopic dermatitis. Invest. Dermatol. 1992, 99, 306-309.

(14) Dhanrajani, P. J. Papillon-Lefevre syndrome: clinical presentation and a brief review. Oral Surg., Oral Med., Oral Pathol., Oral Radiol., Endodontol. 2009, 108, 1-7.

(15) Moroy, G.; Alix, A. J.; Sapi, J.; Hornebeck, W.; Bourguet, E. Neutrophil elastase as a target in lung cancer. Anticancer Agents Med. Chem. 2012, 12, 565-579.

(16) Ohbayashi, H. Novel neutrophil elastase inhibitors as a treatment for neutrophil-predominant inflammatory lung diseases. IDrugs 2002, 5, 910-923.

(17) Zhong, J.; Groutas, W. C. Recent developments in the design of mechanism-based and alternate substrate inhibitors of serine proteases. Curr. Top. Med. Chem. 2004, 4, 1203-1216.

(18) Kelly, E.; Greene, C. M.; McElvaney, N. G. Targeting neutrophil elastase in cystic fibrosis. Expert Opin. Ther. Targets 2008, 12, 145157.

(19) Groutas, W. C.; Dou, D.; Alliston, K. R. Neutrophil elastase inhibitors. Expert Opin. Ther. Pat. 2011, 21, 339-354.

(20) Sjö, P. Neutrophil elastase inhibitors: recent advances in the development of mechanism-based and nonelectrophilic inhibitors. Future Med. Chem. 2012, 4, 651-660.

(21) Iwata, K.; Doi, A.; Ohji, G.; Oka, H.; Oba, Y.; Takimoto, K.; Igarashi, W.; Gremillion, D. H.; Shimada, T. Effect of neutrophil elastase inhibitor (Sivelestat sodium) in the treatment of acute lung injury (ALI) and acute respiratory distress (ARDS): a systematic review and meta-analysis. Intern. Med. 2010, 49, 2423-2432.

(22) Kawabata, K.; Suzuki, M.; Sugitani, M.; Imaki, K.; Toda, M.; Miyamoto, T. ONO-5046, a novel inhibitor of human neutrophil elastase. Biochem. Biophys. Res. Commun. 1991, 177, 814-820.
(23) Stockley, R.; De Soyza, A.; Gunawardena, K.; Perrett, J.; Forsman-Semb, K.; Entwistle, N.; Snell, N. Phase II study of a neutrophil elastase inhibitor (AZD9668) in patients with bronchiectasis. Respir. Med. 2013, 107, 524-533.

(24) Vogelmeier, C.; Aquino, T. O.; O'Brien, C. D.; Perrett, J.; Gunawardena, K. A. A randomised, placebo-controlled, dose-finding study of AZD9668, an oral inhibitor of neutrophil elastase, in patients with chronic obstructive pulmonary disease treated with tiotropium. COPD: J. Chronic Obstruct. Pulm. Dis. 2012, 9, 111-120.

(25) Crocetti, L.; Giovannoni, M. P.; Schepetkin, I. A.; Quinn, M. T.; Khlebnikov, A. I.; Cilibrizzi, A.; Dal Piaz, V.; Graziano, A.; Vergelli, C. Design, synthesis and evaluation of $\mathrm{N}$-bezoylindazole derivatives and analogues as inhibitors of human neutrophil elastase. Bioorg. Med. Chem. 2011, 19, 4460-4472.

(26) Khlebnikov, A. I.; Schepetkin, I. A.; Quinn, M. T. Structureactivity relationship analysis of $\mathrm{N}$-benzoylpyrazoles for elastase inhibitory activity: a simplified approach using atom pair descriptors. Bioorg. Med. Chem. 2008, 16, 2791-2802.

(27) Schepetkin, I. A.; Khlebnikov, A. I.; Quinn, M. T. NBenzoylpyrazoles are novel small molecule inhibitors of human neutrophil elastase. J. Med. Chem. 2007, 50, 4928-4938.

(28) Stadlbauer, W. Product class 2: $1 \mathrm{H}$ - and $2 \mathrm{H}$-indazoles. Sci. Synth. 2002, 12, 227-324.

(29) Piozzi, F.; Ronchi, A. U. Synthesis of substituted 3-indazole ketones. Gazz. Chim. Ital. 1963, 93, 3-14.

(30) Foloppe, N.; Fisher, L. M.; Francis, G.; Howes, R.; Kierstan, P.; Potter, A. Identification of a buried pocket for potent and selective inhibition of Chk1: prediction and verification. Bioorg. Med. Chem. 2006, 14, 1792-1804.

(31) Shatalov, G. V.; Preobrazhenskii, S. A.; Mikhant'ev, B. I. New highly active monomers with pyrazole and indazole rings. Izv. Vyssh. Uchebn. Zaved., Khim. Khim. Tekhnol. 1977, 20, 292-293.

(32) Bistocchi, G. A.; De Meo, G.; Pedini, M.; Ricci, A.; Brouilhet, H.; Boucherie, S.; Rabaud, M.; Jacquignon, P. N1-Substituted $1 H$ indazole-3-ethyl carboxylates and $1 \mathrm{H}$-indazole-3-hydroxamic acids. Farmaco 1981, 36 (5), 315-333.

(33) Buchstaller, H. P.; Wilkinson, K.; Burek, K.; Nisar, Y. Synthesis of 3-indazolecarboxylic esters and amides via Pd-catalyzed carbonylation of 3-iodoindazoles. Synthesis 2011, 19, 3089-3098.

(34) Xie, W.; Herbert, B.; Schumacher, R.; Ma, J.; Nguyen, T. M.; Gauss, C. M.; Yehim, A. 1H-Indazoles, benzothiazoles, 1,2benzoisoxazoles, 1,2-benzoisothiazoles, and choromones and preparation and uses thereof. PCT Int. Appl. WO111038A2, 2005.

(35) Snyder, H. R.; Thompson, C. B.; Hinman, R. L. The synthesis of an indazole analog of DL-tryptophan. J. Am. Chem. Soc. 1952, 74, 2009-2012.

(36) Somasekhara, S.; Dighe, V. S.; Suthar, G. K.; Mukherjee, S. L. Chlorosolfonation of isatins. Curr. Sci. 1965, 34 (17), 508.

(37) Buu-Hoi, N. P.; Hoeffinger, J. P.; Jacquignon, P. Indazole-3carboxylic acids and their derivatives. J. Heterocycl. Chem. 1964, 1 (5), 239-241.

(38) Schumacher, R.; Danca, M. D.; Ma, J.; Herbert, B.; Nguyen, T. M.; Xie, W.; Tehim, A. Preparation of azabicyclic derivatives of indazoles, benzothiazoles, benzoisothiazoles, benzisoxazoles, pyrazolopyridines, isothiazolopyridines for therapeutic use as $\alpha 7-\mathrm{nACh}$ receptor activators. PCT Int. Appl. WO 2007038367, A1 20070405, 2007.

(39) Xie, W.; Herbert, B.; Ma, J.; Nguyen, T. M.; Schumacher, R.; Gauss, C. M.; Tehim, A. Indoles, $1 H$-indazoles, 1,2-benzisoxazoles, and 1,2-benzisothiazoles, and preparation and uses thereof. PCT Int. Appl. WO 2005063767, A2 20050714, 2005.

(40) Savitskaya, N. V.; Tarasevich, E. S.; Shchukina, M. N. Some derivatives of 5-nitro and 5-amino-3-indazolecarboxylic acid. $Z$ h. Obshch. Khim. 1961, 31, 3255-3257.

(41) Navia, M. A.; McKeever, B. M.; Springer, J. P.; Lin, T. Y.; Williams, H. R.; Fluder, E. M.; Dorn, C. P.; Hoogsteen, K. Structure of human neutrophil elastase in complex with a peptide chloromethyl ketone inhibitor at $1.84 \AA$ resolution. Proc. Natl. Acad. Sci. U. S. A. 1989, 86, 7-11. 
(42) Burgi, H. B.; Dunitz, J. D.; Lehn, J. M.; Wipff, G. Stereochemistry of reaction paths at carbonyl centers. Tetrahedron 1974, 30, 1563-1572.

(43) Vergely, I.; Laugaa, P.; Reboud-Ravaux, M. Interaction of human leukocyte elastase with a $N$-aryl azetidinone suicide substrate: conformational analyses based on the mechanism of action of serine proteinases. J. Mol. Graphics 1996, 14 (145), 158-167.

(44) Peters, M. B.; Merz, K. M. Semiempirical comparative binding energy analysis (SE-COMBINE) of a series of trypsin inhibitors. J. Chem. Theory Comput. 2006, 2, 383-399.

(45) Dodson, G.; Wlodawer, A. Catalytic triads and their relatives. Trends Biochem. Sci. 1998, 23, 347-352.

(46) Katona, G.; Wilmouth, R. C.; Wright, P. A.; Berglund, G. I.; Hajdu, J.; Neutze, R.; Schofield, C. J. X-ray structure of a serine protease acyl-enzyme complex at 0.95-Å resolution. J. Biol. Chem. 2002, 277, 21962-21970.

(47) Forist, A. A.; Weber, D. J. Kinetics of hydrolysis of hypoglycemic 1-acyl 3,5-dimethylpyrazoles. J. Pharm. Sci. 1973, 62, 318-319. 